\title{
Soil greenhouse gas emissions under different land-use types in savanna ecosystems of Kenya
}

\author{
Sheila Wachiye ${ }^{1,2,5}$, Lutz Merbold ${ }^{3}$, Timo Vesala ${ }^{2}$ Janne Rinne $^{4}$, Matti Räsänen ${ }^{2}$, Sonja Leitner ${ }^{3}$, and Petri Pellikka ${ }^{1,2}$ \\ ${ }^{1}$ Earth Change Observation Laboratory, Department of Geosciences and Geography, University of Helsinki, Helsinki, Finland \\ ${ }^{2}$ Institute for Atmosphere and Earth System Research, University of Helsinki, Helsinki, Finland \\ ${ }^{3}$ Mazingira Centre, International Livestock Research Institute (ILRI), Nairobi, Kenya \\ ${ }^{4}$ Department of Physical Geography and Ecosystem Science, Lund University, Lund, Sweden \\ ${ }^{5}$ School of Natural Resource and Environmental Management, University of Kabianga, Kericho, Kenya
}

Correspondence: Sheila Wachiye (sheila.wachiye@helsinki.fi)

Received: 6 October 2019 - Discussion started: 23 October 2019

Revised: 3 March 2020 - Accepted: 11 March 2020 - Published: 20 April 2020

\begin{abstract}
Field measurement data on greenhouse gas (GHG) emissions are still scarce for many land-use types in Africa, causing a high level of uncertainty in GHG budgets. To address this gap, we present in situ measurements of carbon dioxide $\left(\mathrm{CO}_{2}\right)$, nitrous oxide $\left(\mathrm{N}_{2} \mathrm{O}\right)$, and methane $\left(\mathrm{CH}_{4}\right)$ emissions from the lowlands of southern Kenya. We conducted eight chamber measurement campaigns on gas exchange from four dominant land-use types (LUTs) comprising (1) cropland, (2) bushland, (3) grazing land, and (4) conservation land between 29 November 2017 and 3 November 2018, accounting for regional seasonality (wet and dry seasons and transitions periods). Mean $\mathrm{CO}_{2}$ emissions for the whole observation period were the highest by a significant margin $(p$ value $<0.05)$ in the conservation land ( $75 \pm 6 \mathrm{mg} \mathrm{CO}_{2}-\mathrm{Cm}^{-2} \mathrm{~h}^{-1}$ ) compared to the three other sites, which ranged from $45 \pm 4 \mathrm{mg} \mathrm{CO}_{2}-\mathrm{C} \mathrm{m}^{-2} \mathrm{~h}^{-1}$ (bushland) to $50 \pm 5 \mathrm{mg} \mathrm{CO}_{2}-\mathrm{C} \mathrm{m}^{-2} \mathrm{~h}^{-1}$ (grazing land). Furthermore, $\mathrm{CO}_{2}$ emissions varied between seasons, with significantly higher emissions in the wet season than the dry season. Mean $\mathrm{N}_{2} \mathrm{O}$ emissions were highest in cropland $\left(2.7 \pm 0.6 \mu \mathrm{g} \mathrm{N}_{2} \mathrm{O}-\mathrm{N} \mathrm{m}^{-2} \mathrm{~h}^{-1}\right)$ and lowest in bushland $(1.2 \pm$ $0.4 \mu \mathrm{g} \mathrm{N}_{2} \mathrm{O}-\mathrm{N} \mathrm{m}^{-2} \mathrm{~h}^{-1}$ ) but did not vary with season. In fact, $\mathrm{N}_{2} \mathrm{O}$ emissions were very low both in the wet and dry seasons, with slightly elevated values during the early days of the wet seasons in all LUTs. On the other hand, $\mathrm{CH}_{4}$ emissions did not show any significant differences across LUTs and seasons. Most $\mathrm{CH}_{4}$ fluxes were below the limit of detection (LOD, $\pm 0.03 \mathrm{mg} \mathrm{CH}_{4}-\mathrm{C} \mathrm{m}^{-2} \mathrm{~h}^{-1}$ ). We attributed the difference in soil $\mathrm{CO}_{2}$ emissions between the four sites to
\end{abstract}

soil $\mathrm{C}$ content, which differed between the sites and was highest in the conservation land. In addition, $\mathrm{CO}_{2}$ and $\mathrm{N}_{2} \mathrm{O}$ emissions positively correlated with soil moisture, thus an increase in soil moisture led to an increase in emissions. Furthermore, vegetation cover explained the seasonal variation in soil $\mathrm{CO}_{2}$ emissions as depicted by a strong positive correlation between the normalized difference vegetation index (NDVI) and $\mathrm{CO}_{2}$ emissions, most likely because, with more green (active) vegetation cover, higher $\mathrm{CO}_{2}$ emissions occur due to enhanced root respiration compared to drier periods. Soil temperature did not show a clear correlation with either $\mathrm{CO}_{2}$ or $\mathrm{N}_{2} \mathrm{O}$ emissions, which is likely due to the low variability in soil temperature between seasons and sites. Based on our results, soil $\mathrm{C}$, active vegetation cover, and soil moisture are key drivers of soil GHG emissions in all the tested LUTs in southern Kenya. Our results are within the range of previous GHG flux measurements from soils from various LUTs in other parts of Kenya and contribute to more accurate baseline GHG emission estimates from Africa, which are key to reducing uncertainties in global GHG budgets as well as for informing policymakers when discussing low-emission development strategies.

\section{Introduction}

Soil is a major source, and in many cases also a sink, of the atmospheric greenhouse gases (GHGs) carbon dioxide $\left(\mathrm{CO}_{2}\right)$, nitrous oxide $\left(\mathrm{N}_{2} \mathrm{O}\right)$, and methane $\left(\mathrm{CH}_{4}\right.$; Oertel et 
al., 2016). The concentrations of these gases have increased since the onset of the industrial revolution (from about 1750), leading to global warming (IPCC, 2013). GHGs trap the long-wave radiation emitted by the Earth's surface, thus increasing surface temperatures (Arrhenius, 1896). Soil $\mathrm{CO}_{2}$ emissions originate from root and mycorrhiza respiration and heterotrophic decomposition of soil organic matter (Oertel et al., 2016). In addition to being a $\mathrm{CO}_{2}$ source, by increasing the soil organic carbon (SOC) content, soils can also act as a sink for $\mathrm{CO}_{2} . \mathrm{N}_{2} \mathrm{O}$ on the other hand can be produced from many pathways in the soil nitrogen $(\mathrm{N})$ cycle but is considered to result primarily from nitrification and denitrification (Butterbach-Bahl et al., 2013). $\mathrm{N}_{2} \mathrm{O}$ uptake into soils is also possible as observed previously (e.g. Butterbach-Bahl et al., 2002; Rosenkranz et al., 2006; Flechard et al., 2005), and it depends on the complete reduction of $\mathrm{N}_{2} \mathrm{O}$ to $\mathrm{N}_{2}$, the ease of $\mathrm{N}_{2} \mathrm{O}$ diffusion within the soil profile, and the dissolution of $\mathrm{N}_{2} \mathrm{O}$ in soil water (Chapuis-Lardy et al., 2007). $\mathrm{CH}_{4}$ is produced by methanogenesis under anaerobic conditions and consumed by methanotrophic microorganisms under aerobic conditions, with the latter being more important in wellaerated upland soils, which consequently show net $\mathrm{CH}_{4}$ uptake (i.e. negative flux; Serrano-Silva et al., 2014; Hanson and Hanson, 1996).

The production and consumption of soil GHGs largely depend on soil physical and chemical properties (Davidson and Janssens, 2006; e.g. texture, soil organic matter, and pH) and are further driven by environmental factors such as soil moisture and soil temperature (Davidson and Janssens, 2006). In addition, vegetation affects both biotic and abiotic factors that drive soil emissions (Raich and Tufekcioglu, 2000; Pinto et al., 2002) and net carbon assimilation (La Scala et al., 2000). Vegetation type directly influences soil physicochemical properties, which in turn modify soil microbial activities (Raich and Tufekcioglu, 2000). It also controls the quantity of plant carbon allocated below ground (Metcalfe et al., 2011) by determining root biomass and litter quality and quantity (Fanin et al., 2011; Rey et al., 2011). Vegetation composition additionally affects root respiration and the associated microbial components. Active roots add directly to soil respiration, while dead roots and root exudates provide carbon as a source of energy and nutrients for soil microbial biomass (Tufekcioglu et al., 2001). Hence, changes in vegetation types and cover due to land-use system and landuse management activities have the potential to modify the soil-to-atmosphere GHG exchange (Raich and Tufekcioglu 2000). Thus, soil GHG emissions and uptake along with their controlling factors differ between biomes based on land use and land-use management.

Land-use changes are reportedly the largest source of anthropogenic GHG emissions in Africa (Valentini et al., 2014). However, in situ studies on GHG emissions from various ecosystems in Africa remain scarce, particularly from savanna ecosystems (Castaldi et al., 2006). Savanna is an important land-cover type in Africa, covering more than
$40 \%$ of its total area (Scholes et al., 1997). In Kenya, savanna and grassland ecosystems cover about $80 \%$ of the total area, comprising various land-use types (LUTs; GoK, 2013). These ecosystems are subject to accelerating land-use change (Grace et al., 2006) due to population growth (Meyer and Turner, 1992) and land-use management activities (Valentini et al., 2014). Conversion of savanna for small- and largescale livestock production, crop cultivation, and human settlement is common in Africa (Bombelli et al., 2009). As a consequence, vegetation cover, net primary productivity, and allocation of carbon and nutrients in plants and soil (Burke et al., 1998) as well as soil GHG emissions are affected (Abdalla et al., 2018; Carbone et al., 2008).

Overgrazing due to overstocking is a major cause of soil and vegetation degradation in large parts of African savannas (Patton et al., 2007; Abdalla et al., 2018). Factors associated with grazing include animal feeding preferences for specific plant species, thus creating higher pressure for those species, which decline in numbers over time, leading to species loss and lower pasture nutritive value (Patton et al., 2007). In addition, soil trampling increases soil bulk density and reduces soil water infiltration (Patton et al., 2007). Furthermore, high rates of dung and urine deposition, especially around homesteads and waterholes, create high $\mathrm{N}$ concentrations that are toxic for many savanna grass species, affecting vegetation cover and composition (e.g. increase in encroaching species such as Solanum incanum L., which is toxic to livestock; van Vegten, 1984). Given that all these factors affect soil properties, soil GHG emissions are most likely similarly affected (Wilsey et al., 2002).

In addition to overgrazing, rapid human population growth has led to more people migrating into savanna ecosystems, which has led to the expansion of cropland (Pellikka et al., 2018; Patton et al., 2007). Brink and Eva (2009) found that the cropland area increased by $57 \%$ between 1975 and 2000 in Africa. In the Horn of Africa, cropland areas increased by $28 \%$ between 1990 and 2010 (Brink et al., 2014), while wooded vegetation in east Africa decreased by $5 \%$ in forests, $16 \%$ in woodlands, and $19 \%$ in shrublands (Pfeifer et al., 2013). As an additional example, in our study area, Taita-Taveta County in southern Kenya, the cropland area increased from $30 \%$ in 1987 to $43 \%$ in 2011 (Pellikka et al., 2018). However, in the Taita Hills, located in the county, this trend has slowed down in recent years, while the savanna lowlands are still being cleared to make way for new cropland (Pellikka et al., 2013).

Croplands in the Kenyan savannas are mostly managed by smallholder farmers (Waswa and Mburu, 2006). Due to high poverty levels in this region, inputs to improve crop yields, such as the use of fertilizer and herbicides and mechanized farming, are minor (Waswa and Mburu, 2006; CIDP, 2014). Thus, an increase in productivity is mostly via cropland expansion. In spite of this, these smallholder farms are likely to have substantial effects on national GHG emission budgets (Pelster et al., 2017). Until now, only a few stud- 
ies have investigated soil GHG emissions from such agricultural landscapes (Rosenstock et al., 2016), and these studies were mostly carried out in high-potential farming areas such as the Kenyan highlands, which receive $>1000 \mathrm{~mm}$ rainfall per year (FAO, 1996). For example, Rosenstock et al. (2016) showed a large variation in $\mathrm{CO}_{2}$ and $\mathrm{N}_{2} \mathrm{O}$ emissions both within and between four crop types as affected by environmental conditions and land management. However, studies measuring GHG emissions from low-productivity croplands in southern Kenya are to the best of our knowledge still missing. Thus, this study focused on soil GHG emissions from different LUTs relevant to the semi-arid region of southern Kenya.

Given the vast area covered by savanna, land use and landcover changes are likely to affect global, regional, and national $\mathrm{C}$ and $\mathrm{N}$ cycles, and hence the quantification of their role is vital (Lal, 2004; Williams et al., 2007). Studies in Kenya have shown large variations in soil GHG emissions in various savanna ecosystems (Otieno et al., 2010; Oduor et al., 2018), due to land use (Ondier et al., 2020) and management activities (K'Otuto et al., 2013). Owing to the high diversity of these savanna ecosystems, such studies may not be entirely representative of every region (Ardö et al., 2008).

The lack of reliable soil GHG flux data from natural savanna and cropland limits our understanding of GHG emissions from African soils (Hickman et al., 2014; Valentini et al., 2014). At the same time, accurate quantification of GHG emissions from multiple LUTs is essential to allow for the reliable estimation of Kenya's national GHG inventory (IPCC, 2019). This is particularly important as Kenya currently relies on a Tier- 1 approach by using default emission factors (EFs) provided in the 2006 IPCC Guidelines for National Greenhouse Gas Inventories of the UN Intergovernmental Panel on Climate Change (IPCC) to estimate national GHG emission budgets. Following the Paris Agreement (https://unfccc.int/ process-and-meetings/the-paris-agreement/d2hhdC1pcy, last access: 29 May 2019), most countries across the globe, including Kenya, have agreed not only to accurately report their GHG emissions at national scales following a Tier-2 approach (i.e. using localized data) but also to mitigate anthropogenic GHG emissions in the upcoming decades, as is communicated via their nationally determined contributions (NDCs). Both can only be achieved with locally derived data.

To address the lack of localized GHG emission data from different LUTs in Kenya, our study aims at (1) providing crucial baseline data on soil GHG emissions from four dominant land uses, namely conservation land, grazing land, bushland, and cropland, and (2) investigating abiotic and biotic drivers of GHG emissions during different seasons. We hypothesized that GHG emissions in cropland would be higher compared to grazing land, bushland, and conservation land because of larger nutrient inputs (i.e. fertilization) in managed land. Further, we hypothesized that GHG emissions would differ between seasons; more precisely, we expected higher GHG emissions in the wet season than in the dry season caused by higher soil moisture.

\section{Materials and methods}

\subsection{Study area}

This study was conducted in the lowlands $(800-1000 \mathrm{~m}$ above sea level (a.s.l.)) of Taita-Taveta County $\left(3^{\circ} 25^{\prime} \mathrm{S}\right.$, $38^{\circ} 20^{\prime}$ E) located in southern Kenya (Fig. 1). Taita-Taveta County is one of Kenya's dryland areas, with $89 \%$ of the area characterized as arid and semi-arid. The county is divided into three major geographical regions, namely the mountainous zone of the Taita Hills (Dawida, Kasigau, Sagalla), the Taita lowlands, and the foot slopes of Mt. Kilimanjaro around Taveta. In the lowlands, vegetation types include woodlands, bushlands, grasslands, and riverine forests and swamps. Tsavo East and Tsavo West national parks covers ca. $62 \%$ of the county area (CIDP, 2014). The parks are open savanna and bushland that support large herbivores, predators, and a wealth of birdlife. There are 28 ranches designated for livestock production and two wildlife sanctuaries (Taita Hills Wildlife Sanctuary and LUMO Community Wildlife Sanctuary). Other important land uses include cropland under small-scale farming (CIDP, 2014), shrublands, and sisal farming (Pellikka et al., 2018). Soil type is characterized by very deep, acidic, dark red, sandy clay soil (Ferralsols). Our study sites were located in four of these key land-use types in the region, i.e. cropland, bushland, wildlife conservation land, and grazing land.

The lowland has a bimodal rainfall pattern with two rainy seasons - a long rain season between March and May and a short rain season between October and December (CIDP, 2014). The hot and dry months are January and February, while the dry season from June to October is cooler (Pellikka et al., 2018). Mean annual rainfall is $500 \mathrm{~mm}$ and the mean annual air temperature is $23^{\circ} \mathrm{C}$, with an average daily minimum and maximum temperature of 16.7 and $28.8^{\circ} \mathrm{C}$ respectively (CIDP, 2014).

The first site investigated is cropland located in Maktau (1070 m a.s.l.; Figs. 1, 2a) about 1.5 ha and cultivated with maize (Zea mays L.) intercropped with beans. The farm is a typical rain-fed smallholder farm, and crop growing closely follows the rainy seasons, with sowing in March and harvesting in June for beans and August for maize. Animal ploughing is carried out to prepare land before seeding, and weeding is by hand hoeing. Small quantities of fresh and dry manure (roughly $20 \mathrm{~kg}$, accounting for less than $1 \mathrm{~kg}$ of N) were used every month to improve soil fertility.

The second site is located in a private bushland in Maktau next to the cropland (1076 ma.s.l.; Figs. 1, 2b). In this region, bushland is found both within the conservation areas and under private ownership. Bushland forms a cover with 


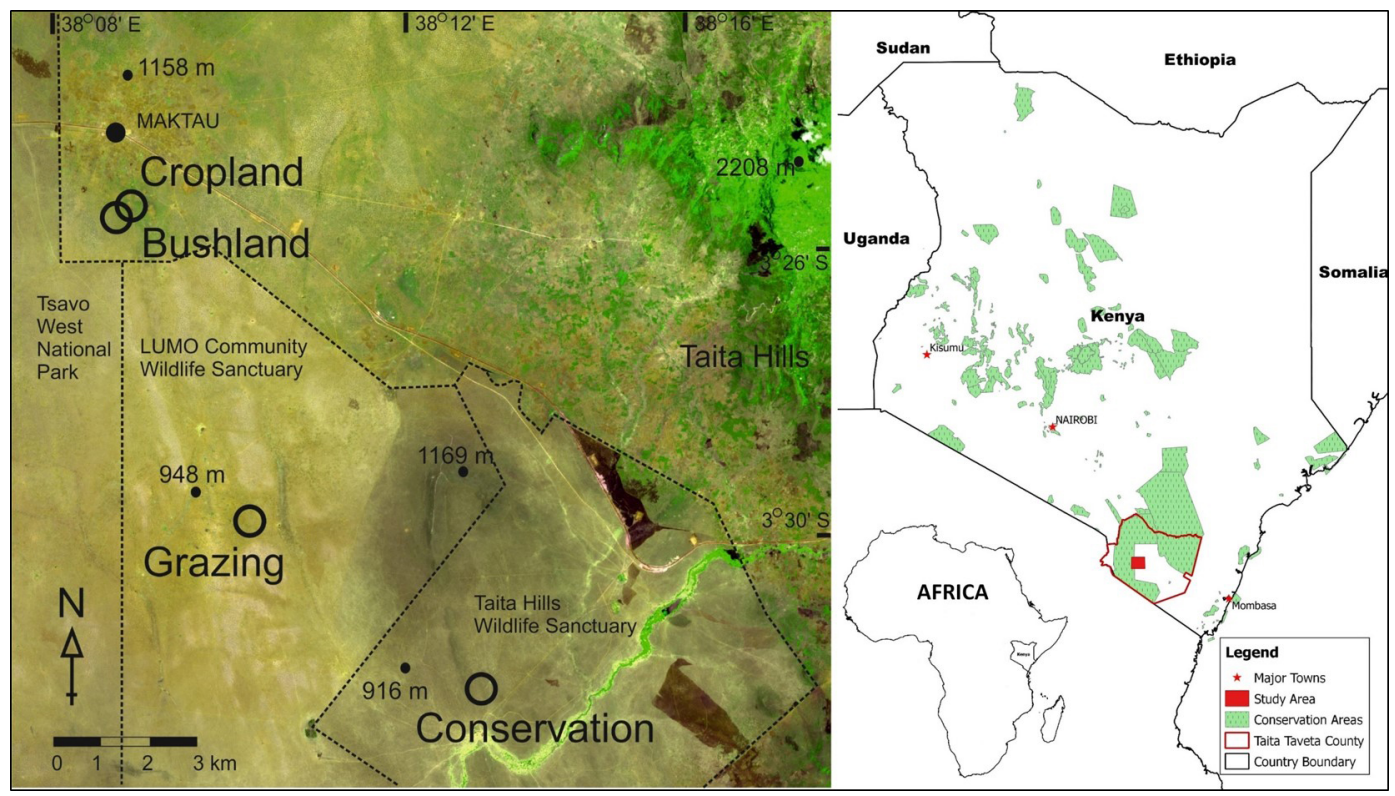

Figure 1. Location of the study sites showing the cropland, bushland, grazing land, and conservation land sites in the savanna area in the lowlands of Taita-Taveta County in southern Kenya. The image showing the sites is from Sentinel-2A acquired from the Sentinels Scientific Data Hub (ESA, 2015). The Kenyan and African boundaries are from @ World Resources Institute (retrieved from https://www.wri.org/ resources/data-sets/kenya-gis-data, last access:14 February 2019).

over $50 \%$ of thorny shrubs and small trees, characterized by Acacia spp. and Commiphora spp. The bushes may vary in height ranging from 2 to $5 \mathrm{~m}$. Herbs and savanna grasses (mostly annual or short-lived perennials) less than $1 \mathrm{~m}$ tall form the ground cover. Private bushland similar to that of our study site is used by farmers to generate small income from forest products such as timber; poles; firewood; and, to some extent, charcoal. Additionally, some grazing occurs primarily by livestock owned by the farmer (CIDP, 2014).

The third site, grazing land (covering approximately $460 \mathrm{~km}^{2}$ ) is located in the LUMO Community Wildlife Sanctuary (970 ma.s.l; Figs. 1, 2c) next to Tsavo West National Park and Taita Hills Wildlife Sanctuary. The sanctuary was formed by merging three ranches, namely the Lualenyi and Mramba communal grazing areas and the Oza group ranch, thus the name LUMO. This sanctuary is communally owned (GoK, 2013) and designated for community livestock grazing where wildlife is also present, as conservation areas are not necessarily fenced. However, overgrazing is a major challenge, caused by herders who enter the conservancy illegally especially in the dry season (CIDP, 2014).

The fourth site is the conservation land located within the Taita Hills Wildlife Sanctuary (928 m a.s.l.; Figs. 1, 2d) covering an area of ca. $110 \mathrm{~km}^{2}$. This is a private game sanctuary for wildlife conservation located between LUMO and communal land. The sanctuary is an open savanna grassland dominated by Schmidtia bulbosa and Cenchrus ciliaris grass species forming an open to closed ground cover, shrublands, and scattered woodlands with Acacia spp. as the main tree species. However, most trees have been damaged by elephants, leaving the landscape open. The sanctuary is well managed with the application of ecological management tools such as controlled fires. Through these and other conservation efforts, the sanctuary has attracted a high diversity of large mammals, many of which remain within the unfenced sanctuary throughout the year. Wildlife are the predominant grazers and browsers, although livestock encroachment may be a problem especially during the dry season on the western and eastern borders of the sanctuary (GoK, 2013).

\subsection{Defining the seasons}

We divided our campaigns into dry and wet seasons, based on the agroclimatic concept. The onset of the wet season was the first wet day of a $3 \mathrm{~d}$ wet spell receiving at least $20 \mathrm{~mm}$ of rain without any $10 \mathrm{~d}$ dry spell $(<1 \mathrm{~mm})$ in the next $20 \mathrm{~d}$ from 1 March for the long wet season and 1 September for the short wet season (Marteau et al., 2011). Equally, the end of the rainy season was the first of 10 consecutive days with no rain. Thus, for this study, the long wet season (LW) was between 2 March and 4 June 2018 and the short wet season (SW) between 23 October and 26 December 2018. The two wet seasons were separated by two dry seasons, the short dry season (SD) from January to February 2018 and the long dry season (LD) from June to September 2018. We had three campaigns in each of the wet seasons: the early days of the wet seasons onset (onset-SW, onset-LW), the peak of the sea- 


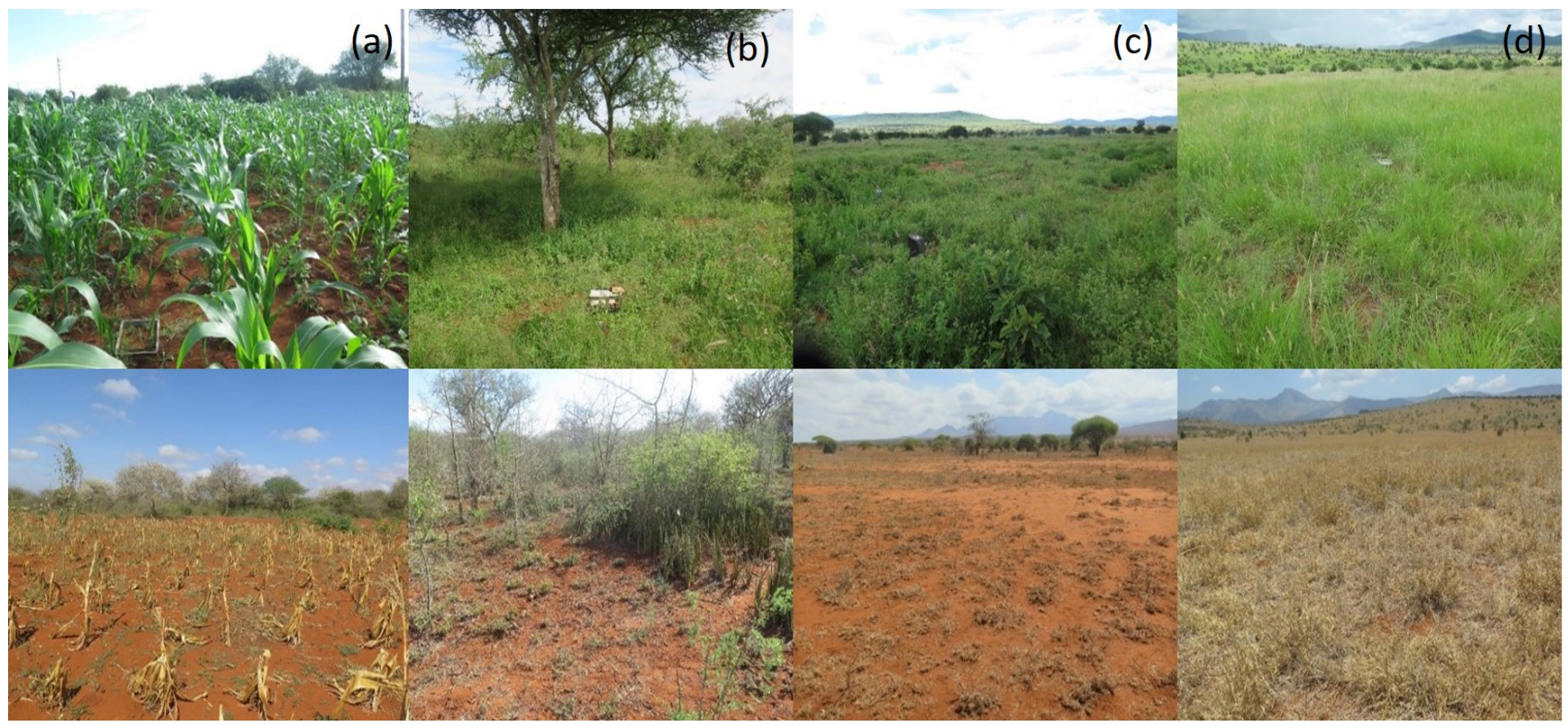

Figure 2. The four land-use types: (a) cropland, (b) bushland, (c) grazing land, and (d) conservation land. The upper row shows the land-use types during the wet season, while the lower row depicts the situation during the dry season. The grey plastic collar visible in the upper left photo is a frame for a GHG flux chamber.

sons (mid-SW, mid-LW), and the end of the seasons (end$\mathrm{SW}$, end-LW).

\subsection{Chamber measurements of greenhouse gas emission}

Soil-atmosphere exchange of $\mathrm{CO}_{2}, \mathrm{~N}_{2} \mathrm{O}$, and $\mathrm{CH}_{4}$ was measured in eight 1-week campaigns from 29 November 2017 to 3 November 2018 using the static chamber method (Rochette, 2011; Hutchinson and Mosier, 1981). Within each of the four sites (LUTs), three clusters were randomly selected as replicates for soil GHG concentration measurements. In each cluster, three plastic collars $(27 \mathrm{~cm} \times 37.2 \mathrm{~cm} \times 10 \mathrm{~cm})$ were inserted 5-8 cm into the soil at least $24 \mathrm{~h}$ before the first sample was taken (see Pelster et al., 2017, for further details). The collars were left in the ground for the entire measurement period to minimize soil disturbance during measurements (Søe et al., 2004). Any damaged or missing collars (mostly due to livestock or wildlife activity) were replaced at least $24 \mathrm{~h}$ before the next gas sampling. During each day of a campaign, gas sampling was conducted daily between 07:00 and 11:00 east Africa time (EAT), which is about the average flux of the diurnal cycle (Parkin and Venterea, 2010).

During each gas-sampling day, grey opaque PVC lids $(27 \mathrm{~cm} \times 37.2 \mathrm{~cm} \times 12 \mathrm{~cm})$ covered with reflective tape were placed onto the collars for $30 \mathrm{~min}$. Lids were fitted with a fan for gas mixing and a vent to avoid pressure differences between the chamber headspace and outside atmosphere (Pelster et al., 2017). A rubber seal was fitted along the edges of the chamber lid, and paper clips were used to hold the lid and collar in place to ensure airtightness. Four gas samples were then collected every $10 \mathrm{~min}$ (time $0,10,20,30 \mathrm{~min}$ ) after lid deployment (Rochette, 2011). The height of each chamber collar was measured on each sampling day to derive the total chamber volume (total chamber height $=$ height of chamber collar sticking out of the soil + height of the chamber lid). A slightly modified version of the gas-pooling method was used to reduce the overall sample size while ensuring a good spatial representation of each LUT (see Arias-Navarro et al., 2013). Here, $20 \mathrm{~mL}$ of headspace air was collected from each of the three chambers at each time interval with polypropylene syringes ( $60 \mathrm{~mL}$ capacity), resulting in a composite gas sample of $60 \mathrm{~mL}$. The first $40 \mathrm{~mL}$ was used to flush the vials, and the remaining $20 \mathrm{~mL}$ was overpressured into $10 \mathrm{~mL}$ glass vials to minimize contamination of the gas with ambient air during transportation (Rochette and Bertrand, 2003).

Gas samples were transported to the laboratory (Mazingira Centre, https://mazingira.ilri.org, last access: 13 April 2020) and analysed using a gas chromatograph (GC; model SRI 8610C). The GC was fitted with a ${ }^{63} \mathrm{Ni}$ electron capture detector (ECD) for detecting $\mathrm{N}_{2} \mathrm{O}$ concentrations and a flame ionization detector (FID) fitted with a methanizer for $\mathrm{CH}_{4}$ and $\mathrm{CO}_{2}$ analysis. The $\mathrm{GC}$ was operated with a HayeSep D packed column (3 m length, $1 / 8$ in. diameter) at an oven temperature of $70^{\circ} \mathrm{C}$, while ECD and FID detectors were operated at a temperature of $350{ }^{\circ} \mathrm{C}$. Carrier gas $\left(\mathrm{N}_{2}\right)$ flow rate was $25 \mathrm{~mL} \mathrm{~min}^{-1}$ on both FID and ECD lines. In every 40 samples analysed with the GC, there were eight calibration gases with known $\mathrm{CO}_{2}, \mathrm{CH}_{4}$, and $\mathrm{N}_{2} \mathrm{O}$ concentrations in synthetic air (levels of calibration gases ranged 
from 400 to $2420 \mathrm{ppm}$ for $\mathrm{CO}_{2}, 360$ to $2530 \mathrm{ppb}$ for $\mathrm{N}_{2} \mathrm{O}$, and 4.28 to $49.80 \mathrm{ppm}$ for $\mathrm{CH}_{4}$ ). Therefore, the gas concentrations of the samples were calculated from peak areas of samples in relation to peak areas of standard gases using a linear model for $\mathrm{CO}_{2}$ and $\mathrm{CH}_{4}$ and a power regression for $\mathrm{N}_{2} \mathrm{O}$ using Eq. (1) which follows.

Conc $_{\mathrm{CO}_{2}, \mathrm{CH}_{4}}=a x+\beta$,

Conc $_{\mathrm{N}_{2} \mathrm{O}}=a x^{\beta,}$

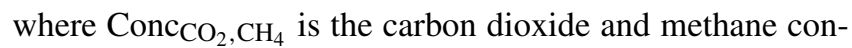
centrations in ppm, Conc $\mathrm{N}_{2} \mathrm{O}$ is the nitrous oxide concentration in ppb, $a$ and $\beta$ are model coefficients, and $x$ is the peak area derived from the GC. Both equations are based on peak area measurements of known standards with our GCs, and while the FID $\left(\mathrm{CO}_{2}\right.$ and $\mathrm{CH}_{4}$ detection) is linear over the entire concentration range, the ECD $\left(\mathrm{N}_{2} \mathrm{O}\right.$ detection) behaves non-linearly, and therefore a power function leads to better fits.

\subsection{Greenhouse gas flux calculations}

Soil GHG emissions were determined by the rate of change in gas concentration in the chamber headspace over time by linear fitting. The goodness of fit was used to evaluate the linearity of concentration increases and decreases. The dynamics of the $\mathrm{CO}_{2}$ concentrations over the $30 \mathrm{~min}$ deployment period for each gas concentration were assessed to test for chamber leakage due to the typically more robust and continuous flux of $\mathrm{CO}_{2}$ (Collier et al., 2014). If the linear model of $\mathrm{CO}_{2}$ versus deployment time had an $R^{2}>0.95$ using all four time points (T1, T2, T3, and T4), the measurement was considered valid and four time points were used for analysing the $\mathrm{CO}_{2}, \mathrm{~N}_{2} \mathrm{O}$, and $\mathrm{CH}_{4}$ emissions. However, if $R^{2}<0.95$ for $\mathrm{CO}_{2}$ and one data point was a clear outlier, this point was discarded and the three remaining points were used for the flux calculation if they showed a strong correlation of $\mathrm{CO}_{2}$ versus time. Measurements that did not show a clear trend of $\mathrm{CO}_{2}$ with time were considered faulty, and the entire data point series was discarded. In addition, data points that showed a decrease in $\mathrm{CO}_{2}$ concentration over time were assumed to indicate leakage and were similarly discarded (chambers were opaque; i.e. photosynthesis was inactive during chamber deployment). However, if no leakage was found, negative $\mathrm{CH}_{4}$ and $\mathrm{N}_{2} \mathrm{O}$ emissions were accepted as the uptake of the respective gas by the soil. Emissions were calculated according to Eq. (3):

$F_{\mathrm{GHG}}=\frac{\left(\frac{\mathrm{d} c}{\mathrm{~d} t}\right) \times V_{\mathrm{ch}} \times M_{\mathrm{w}}}{A_{\mathrm{ch}} \times \mathrm{Mv}_{\mathrm{corr}}} 60 \times 10^{6}$,

where $F_{\mathrm{GHG}}=$ soil GHG flux $\left(\mathrm{CO}_{2}, \mathrm{~N}_{2} \mathrm{O}\right.$, or $\left.\mathrm{CH}_{4}\right)$, $\partial c / \partial t=$ change in chamber headspace gas concentration over time (i.e. slope of the linear regression), $V_{\mathrm{ch}}=$ volume of the chamber headspace $\left(\mathrm{m}^{3}\right), M_{\mathrm{w}}=$ molar weight $\left(\mathrm{g} \mathrm{mol}^{-1}\right)$ of $\mathrm{C}$ for $\mathrm{CO}_{2}$ and $\mathrm{CH}_{4}$ (12) or $\mathrm{N}$ for $\mathrm{N}_{2} \mathrm{O}$ $(2 \times \mathrm{N}=28), A_{\mathrm{ch}}=$ area covered by the chamber $\left(\mathrm{m}^{2}\right)$, and $\mathrm{Mv}_{\text {corr }}=$ pressure- and temperature-corrected molar volume (Brümmer et al., 2008) using Eq. (2), with 60 and $10^{6}$ being, constants used to convert minutes into hours and grams into micrograms respectively. Temperature in Eq. (4) is the air temperature in the chamber headspace measured during each sampling, and 0.02241 is the molar volume of a gas at standard temperature and pressure $\left(\mathrm{m}^{3} \mathrm{~mol}^{-1}\right)$.

$$
\begin{aligned}
\mathrm{Mv}_{\text {corr }} & =0.02241 \frac{273.15+\operatorname{Temp}\left({ }^{\circ} \mathrm{C}\right)}{273.15} \\
& \times \frac{\text { Atmospheric pressure at measurement }(\mathrm{Pa})}{\text { Atmospheric pressure at sea level }(\mathrm{Pa})}
\end{aligned}
$$

The minimum limit of detection (LOD) for each gas was calculated following Parkin et al. (2012), and levels were $\pm 4.9 \mathrm{mg} \mathrm{CO}_{2}-\mathrm{C} \mathrm{m}^{-2} \mathrm{~h}^{-1}$ for $\mathrm{CO}_{2}, \pm 0.04 \mu \mathrm{g} \mathrm{N}_{2} \mathrm{O}$ $\mathrm{N} \mathrm{m}^{-2} \mathrm{~h}^{-1}$ for $\mathrm{N}_{2} \mathrm{O}$, and $\pm 0.03 \mathrm{mg} \mathrm{CH}_{4}-\mathrm{C} \mathrm{m}^{-2} \mathrm{~h}^{-1}$ for $\mathrm{CH}_{4}$. However, we included all data in the analysis, including those below the LOD in line with Croghan and Egeghy (2003), who noted that including such data provides an insight into the distinct measurements, thus clarifying the set of environmental observations.

\subsection{Auxiliary measurements}

During each gas-sampling day, we measured soil water content (WC) and soil temperature $(T$; at a depth of $0-5 \mathrm{~cm})$ adjacent to the collar using a handheld data logger with a GS3 sensor (ProCheck, METER Group, Inc., USA). Daily air temperature and precipitation data from November 2017 to November 2018 were obtained from a weather station in Maktau located within the cropland site (Tuure et al., 2019). A soil auger was used to collect soil samples (at a depth of 0-20 cm) during the wet season (22 May 2018) in each site for soil chemical and physical property analysis. For bulk density, we collected a combination of three samples from each cluster close to each chamber collar at depths of 0 10 and 10-20 cm using a soil bulk density ring (Eijkelkamp Agrisearch Equipment, Giesbeek, the Netherlands). Samples were stored in airtight polyethylene bags and kept in a cooler box with ice packs before transportation to the laboratory for further analysis. In the laboratory, samples were stored in a refrigerator $\left(4^{\circ} \mathrm{C}\right)$ and analysed within $10 \mathrm{~d}$.

The samples were sieved at $<2 \mathrm{~mm}$ before analysis. Soil water content was measured by drying soil at $105^{\circ} \mathrm{C}$ for $48 \mathrm{~h}$. Soil pH was determined in a $1: 2.5$ (soil : distilled water) suspension using an electrode $\mathrm{pH}$ meter $(3540 \mathrm{pH}$ and conductivity meter, Bibby Scientific Ltd, UK), and soil texture was determined using the hydrometer technique (Scrimgeour, 2008; van Reeuwijk, 2002). Total soil C and N content, a duplicate of $20 \mathrm{~g}$ of fresh sample, was oven-dried at $40^{\circ} \mathrm{C}$ for $48 \mathrm{~h}$ and ground into a fine powder using a ball mill (Retsch MM 400). Approximately $200 \mathrm{mg}$ of the dry sample 
was measured by elemental analysis (vario MAX cube analyser Version 05.03.2013).

\subsection{Statistical analysis}

Statistical analyses were carried out using R statistical software (R 3.5.2, R Core Team, 2018). Spearman correlation coefficients were calculated among the variables followed by the Kruskal-Wallis test to assess significant differences in GHG emissions between the LUTs and across seasons. A post hoc analysis involving pairwise comparisons using the Nemenyi test was performed where significant differences existed. The significance level was set at $p<0.05$. We assessed the correlation between soil GHG emissions with $T$ and WC using several functions based on the coefficient of determination $\left(R^{2}\right)$, root-mean-square error (RMSE), and Akaike's information criterion (AIC). There being no difference in the outputs, we present results from the Gaussian function (O'Connell, 1990) for the correlation between soil emissions and $T$ using Eq. (5) and a quadratic function for correlation with WC using Eq. (6). We also evaluated the combined effect of $T$ and WC on soil GHG emissions by combining Eqs. (5) and (6) into Eq. (7) to assess the effect of these two variables on the emissions.

$R_{\mathrm{S}}=a e^{\left(b T+c T^{2}\right)}$,

$R_{\mathrm{S}}=a+b \mathrm{WC}+c \mathrm{WC}^{2}$,

$R_{\mathrm{S}}=e^{\left(a T+b T^{2}\right)} \times\left(c \mathrm{WC}+d \mathrm{WC}^{2}\right)$,

where $R_{\mathrm{s}}$ is soil GHG $\left(\mathrm{CO}_{2}\right.$ and $\left.\mathrm{N}_{2} \mathrm{O}\right)$ emissions, $T$ is soil temperature $\left({ }^{\circ} \mathrm{C}\right)$, and $\mathrm{WC}$ is soil water content $\left(\mathrm{m}^{3} \mathrm{~m}^{-3}\right)$, while $a, b, c$, and $d$ are the model coefficients.

After no correlation with $T$ and a weak correlation with WC were observed, we included vegetation cover. For this, we used the normalized difference vegetation index (NDVI) from the Moderate Resolution Imaging Spectroradiometer (MODIS) available at https://ladsweb.modaps.eosdis.nasa. gov (last access: 22 August 2019). The NDVI quantifies vegetation vigour by measuring the difference between reflectance in near-infrared-wavelength (NIR) areas (which green chlorophyll-rich vegetation strongly reflects) and redwavelength areas (which vegetation absorbs) computed using Eq. (8). MOD13Q1 products from MODIS are NDVI data generated at $16 \mathrm{~d}$ intervals at a $250 \mathrm{~m}$ spatial resolution as a Level 3 product (Didan, 2015).

$\mathrm{NDVI}=\frac{\mathrm{NIR}+\mathrm{Red}}{\mathrm{NIR}+\mathrm{Red}}$

To cover our study period, we selected NDVI data within the campaign dates. If no data fitted within our dates, we used data that were from less than $5 \mathrm{~d}$ before or after the campaign dates, assuming that no significant increase or decrease would occur in the vegetation. The pixels containing the study sites were extracted based on the latitude and longitude of each site. Linear functions were applied to the seasonal datasets of $R_{\mathrm{S}}$ with NDVI to assess the contribution of vegetation on soil emissions using Eq. (9) and a combined effect of WC and NDVI on soil $\mathrm{CO}_{2}$ emissions $\left(R_{\mathrm{S}}\right)$ using Eq. (10).

$$
\begin{aligned}
& R_{\mathrm{S}}=a+b \mathrm{NDVI} \\
& R_{\mathrm{S}}=a+b \mathrm{NDVI}+\left(c \mathrm{WC}+d \mathrm{WC}^{2}\right)
\end{aligned}
$$

\section{Results}

\subsection{Meteorological data}

During the 12-month study period, the long rains lasted from early March to the end of May, while short rains occurred between early September and December (Fig. 3). The total annual rainfall was $550 \mathrm{~mm}$, which is within the average rainfall expected in the area (CIDP, 2014). The mean annual air temperature was $22.7^{\circ} \mathrm{C}\left(\min =16.7^{\circ} \mathrm{C}\right.$, $\left.\max =30.5^{\circ} \mathrm{C}\right)$. January was the hottest month $\left(\min =17.4^{\circ} \mathrm{C}, \max =31.9^{\circ} \mathrm{C}\right)$, while June and July $\left(\min =14.5 \pm 0.2^{\circ} \mathrm{C}, \max =27 \pm 0.1{ }^{\circ} \mathrm{C}\right)$ were the coolest.

\subsection{Soil characteristics}

Sand content was highest in cropland $(77 \pm 8 \%)$ compared to conservation land and bushland (ca. $72 \pm 1 \%$ ) and lowest in grazing land $(64.3 \pm 0.4 \%$; see Table 2$)$. Grazing land had the highest clay content $(31.7 \pm 0.5 \%)$, while cropland $(19 \pm 2 \%)$ had the lowest. Soil $\mathrm{pH}$ ranged between slightly acidic in grazing land $(6.3 \pm 0.3)$, neutral in bushland (7.2 \pm 0.4$)$, and slightly alkaline in conservation land and cropland ( $7.5 \pm 0.1$ and $7.9 \pm 0.2$ respectively). Carbon content ranged from $0.93 \%$ in conservation land to $0.60 \%$ in cropland. Nitrogen content did not vary significantly between sites $($ mean $=0.08 \pm 0.01 \%)$.

\subsection{Soil greenhouse gas emissions}

\subsection{Soil carbon dioxide $\left(\mathrm{CO}_{2}\right)$ emissions}

Mean annual soil $\mathrm{CO}_{2}$ emissions were highest in conservation land $\left(75 \pm 6 \mathrm{mg} \mathrm{CO}_{2}-\mathrm{C} \mathrm{m}^{-2} \mathrm{~h}^{-1}\right)$. Concurrently, no significant differences occurred between grazing land $\left(50 \pm 5 \mathrm{mg} \mathrm{CO}_{2}-\mathrm{C} \mathrm{m}^{-2} \mathrm{~h}^{-1}\right)$, cropland $\quad\left(47 \pm 3 \mathrm{mg} \mathrm{CO}_{2}-\right.$ $\left.\mathrm{C} \mathrm{m}^{-2} \mathrm{~h}^{-1}\right)$, and bushland $\left(45 \pm 4 \mathrm{mg} \mathrm{CO}_{2}-\mathrm{C} \mathrm{m}^{-2} \mathrm{~h}^{-1}\right)$. We observed no significant difference in $\mathrm{CO}_{2}$ emissions between the first three seasons, namely SD, onset-LW, and mid-LW. However, towards the end of the wet season (end-LW) in May, $\mathrm{CO}_{2}$ emissions in conservation land and grazing land were significantly higher than in cropland and bushland $(p<0.05)$. Through the LD, onset-SW, and mid-SW, $\mathrm{CO}_{2}$ emissions in conservation land remained significantly higher, while those in grazing land dropped during the LD and were not different from bushland or cropland emissions thereafter. 


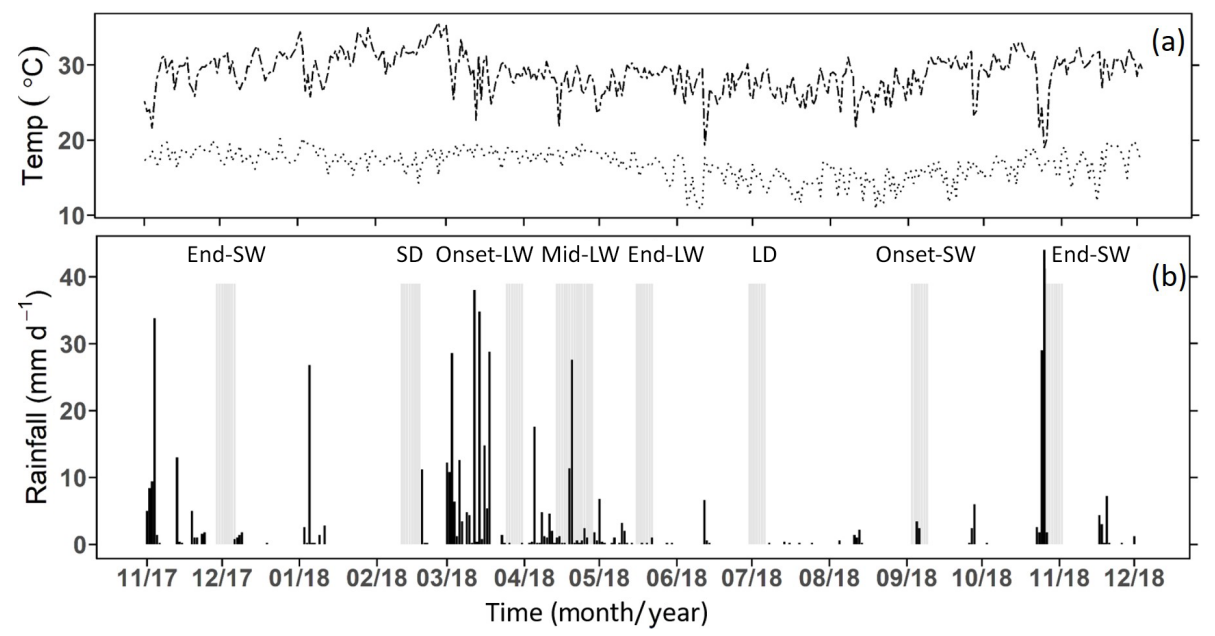

Figure 3. (a) Daily maximum and minimum air temperature and (b) daily rainfall from lowland in southern Kenya between November 2017 to October 2018 recorded at Maktau weather station. Total annual recorded rainfall was $550 \mathrm{~mm}$. Highlighted grey bars show the days of the sampling campaigns (the season labels above the grey bars are SW and LW for the short and long wet seasons and SD and LD for the short and long dry seasons; onset, mid, and end denote the onset, middle and end of the corresponding wet season).

Table 1. Soil characteristics of the topsoil (a depth of $0-20 \mathrm{~cm}$ ) from the four land-use types investigated in this study. Values are given as mean \pm SE.

\begin{tabular}{lrrrrrrr}
\hline Land use & \% N & $\begin{array}{r}\text { \% C } \\
\text { Bulk density }\end{array}$ & $\mathrm{pH}$ & \multicolumn{3}{c}{ Soil texture } \\
\cline { 5 - 8 } & & & & & \% clay & $\%$ sand & $\%$ silt \\
\hline Bushland & $0.08(0.03)$ & $0.77(0.5)$ & $1.31(0.2)$ & $7.2(0.4)$ & $23.7(0.7)$ & $71.6(2.2)$ & $4.7(2.3)$ \\
Conservation land & $0.09(0.02)$ & $0.93(0.7)$ & $1.27(0.4)$ & $7.5(0.1)$ & $26.4(2.2)$ & $71.6(0.5)$ & $2.0(0.0)$ \\
Cropland & $0.07(0.04)$ & $0.60(0.2)$ & $1.26(0.3)$ & $7.9(0.2)$ & $19.1(2.4)$ & $76.9(8.1)$ & $4.0(5.1)$ \\
Grazing land & $0.08(0.02)$ & $0.83(0.4)$ & $1.23(0.5)$ & $6.3(0.3)$ & $31.7(0.5)$ & $64.3(0.4)$ & $4.4(0.4)$ \\
\hline
\end{tabular}

Generally, $\mathrm{CO}_{2}$ emissions were higher in the wet seasons than in the dry seasons at all sites (Fig. 4c). At the onset of the rainy season in early March, $\mathrm{CO}_{2}$ emissions increased at all sites by over $200 \%$ from the SD to LW and dropped during the LD by approximately $70 \%$ in grazing land, bushland, and cropland. In conservation land, the drop from LW to $\mathrm{LD}$ was about $20 \%$. In bushland, the highest seasonal mean fluxes were reached in the mid-LW $\left(98 \pm 6 \mathrm{mg} \mathrm{CO}_{2}\right.$ $\left.\mathrm{C} \mathrm{m}^{-2} \mathrm{~h}^{-1}\right)$, while in conservation land $\left(239 \pm 11 \mathrm{mg} \mathrm{CO}_{2}\right.$ $\left.\mathrm{C} \mathrm{m}^{-2} \mathrm{~h}^{-1}\right)$, grazing land $\left(160 \pm 16 \mathrm{mg} \mathrm{CO}_{2}-\mathrm{C} \mathrm{m}^{-2} \mathrm{~h}^{-1}\right)$, and cropland $\left(84 \pm 12 \mathrm{mg} \mathrm{CO}_{2}-\mathrm{C} \mathrm{m}^{-2} \mathrm{~h}^{-1}\right)$, the highest were observed during the end-LW towards the end May. The lowest seasonal mean $\mathrm{CO}_{2}$ emissions at all sites were observed during the SD campaign (below $20 \mathrm{mg} \mathrm{CO}_{2}-\mathrm{C} \mathrm{m}^{-2} \mathrm{~h}^{-1}$; Fig. 4).

When comparing the two wet seasons ( $\mathrm{LW}$ and $\mathrm{SW}$ ), $\mathrm{CO}_{2}$ emissions were $45 \%$ (bushland), $55 \%$ (conservation land), $56 \%$ (cropland), and $57 \%$ (grazing land) higher in the LW than SW (Fig. 5a). For the two dry seasons, $\mathrm{CO}_{2}$ emissions were significantly higher in the LD than SD across all the sites (in SD all sites recorded emissions below $20 \mathrm{mg} \mathrm{CO}_{2}$ $\left.\mathrm{C} \mathrm{m}^{-2} \mathrm{~h}^{-1}\right)$. During the $\mathrm{LD}, \mathrm{CO}_{2}$ emissions were $29 \%$ (bushland), $38 \%$ (cropland), $40 \%$ (grazing land), and $77 \%$ (conservation) higher than during the SD. Although $\mathrm{CO}_{2}$ emissions in cropland, bushland, and grazing land dropped to less than $30 \mathrm{mg} \mathrm{CO}_{2}-\mathrm{C} \mathrm{m}^{-2} \mathrm{~h}^{-1}$ during the $\mathrm{LD}$, in conservation land $\left(118 \pm 6 \mathrm{mg} \mathrm{CO}_{2}-\mathrm{Cm}^{-2} \mathrm{~h}^{-1}\right)$ the emissions remained high (Fig. 4c).

\subsubsection{Soil nitrous oxide $\left(\mathrm{N}_{2} \mathrm{O}\right)$ emissions}

Mean annual $\mathrm{N}_{2} \mathrm{O}$ emissions were very low $\left(<5 \mu \mathrm{g} \mathrm{N}_{2} \mathrm{O}\right.$ $\mathrm{N} \mathrm{m}^{-2} \mathrm{~h}^{-1}$ ) at all four sites (Fig. 4d). Cropland (2.7 \pm $0.6 \mu \mathrm{g} \mathrm{N}_{2} \mathrm{O}-\mathrm{N} \mathrm{m}^{-2} \mathrm{~h}^{-1}$ ) recorded the highest mean $\mathrm{N}_{2} \mathrm{O}$ emissions compared to conservation land $\left(1.6 \pm 0.4 \mu \mathrm{g} \mathrm{N} \mathrm{N}_{2} \mathrm{O}\right.$ $\mathrm{N} \mathrm{m}^{-2} \mathrm{~h}^{-1}$ ), grazing land $\left(1.5 \pm 0.4 \mu \mathrm{g} \mathrm{N}_{2} \mathrm{O}-\mathrm{N} \mathrm{m}^{-2} \mathrm{~h}^{-1}\right)$, and bushland $\left(1.2 \pm 0.4 \mu \mathrm{g} \mathrm{N}_{2} \mathrm{O}-\mathrm{N} \mathrm{m}^{2} \mathrm{~h}^{-1}\right) . \mathrm{N}_{2} \mathrm{O}$ emissions did not show a clear temporal pattern as observed for $\mathrm{CO}_{2}$ emissions. Within each season, no significant differences in $\mathrm{N}_{2} \mathrm{O}$ emissions were observed among the sites. However, at the onset of the rainy season (onset-LW), there were observable increases in $\mathrm{N}_{2} \mathrm{O}$ emissions from all the sites. During this period, mean $\mathrm{N}_{2} \mathrm{O}$ emissions at all the sites were ca. $2.6 \pm 0.4 \mu \mathrm{g} \mathrm{N}_{2} \mathrm{O}-\mathrm{N} \mathrm{m}^{-2} \mathrm{~h}^{-1}$. By the mid-LW and endLW, $\mathrm{N}_{2} \mathrm{O}$ emissions had dropped $\left(<1 \mu \mathrm{g} \mathrm{N}_{2} \mathrm{O}-\mathrm{N} \mathrm{m}^{-2} \mathrm{~h}^{-1}\right)$ 

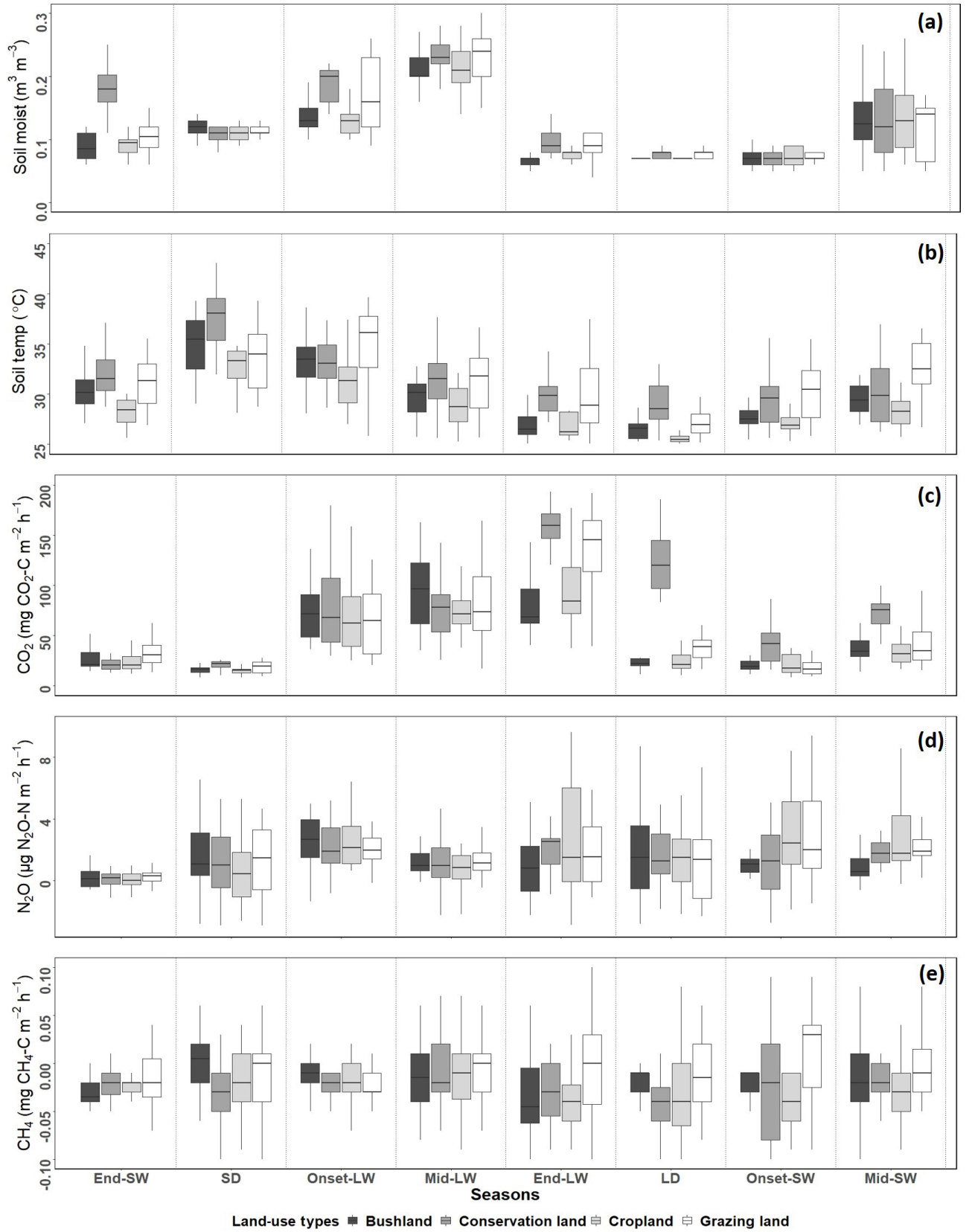

Figure 4. Box plots showing differences in seasonal means for (a) soil moisture and (b) soil temperature and for soil emissions of (c) $\mathrm{CO}_{2}$, (d) $\mathrm{N}_{2} \mathrm{O}$, and (e) $\mathrm{CH}_{4}$ for each site from November 2017 to October 2018. Season abbreviations on the $x$ axis are SW for the short wet season and LW for the long wet season, with onset, middle (mid) and end of the corresponding wet season also shown, along with SD for the short dry season and LD for the long dry season.

at all sites. In June during the $\mathrm{LD}, \mathrm{N}_{2} \mathrm{O}$ emissions in cropland were significantly higher than at the other three sites $\left(2.35 \pm 0.03 \mu \mathrm{g} \mathrm{N} \mathrm{N}_{2} \mathrm{O}-\mathrm{N} \mathrm{m}^{-2} \mathrm{~h}^{-1}, p<0.05\right)$. During this period, the farmer had just harvested their crops.

When comparing the two wet seasons, $\mathrm{N}_{2} \mathrm{O}$ emissions did not differ between the LW and SW at all sites (Fig. 5b). However, short $\mathrm{N}_{2} \mathrm{O}$ emission pulses were observed during both seasons. A notable peak of about $70 \mu \mathrm{g} \mathrm{N} \mathrm{N}_{2} \mathrm{O}-\mathrm{N} \mathrm{m}^{-2} \mathrm{~h}^{-1}$ was observed in cropland on 7 April 2018, a week after livestock manure application. It had also rained the night before the sampling day. At the same site, we also recorded a peak of $55.2 \mu \mathrm{g} \mathrm{N} \mathrm{N}_{2} \mathrm{O}-\mathrm{N} \mathrm{m}^{-2} \mathrm{~h}^{-1}$ on 30 September 2018, likely also due to manure application (personal communication from the farmer Mwadime Mjomba, 12 October 2018). Other notable peaks were $29.9 \mu \mathrm{g} \mathrm{N}_{2} \mathrm{O}-\mathrm{N} \mathrm{m}^{-2} \mathrm{~h}^{-1}$ (in bushland on 3 September 2018) and $26.6 \mu g \mathrm{~N}_{2} \mathrm{O}-\mathrm{N} \mathrm{m}^{-2} \mathrm{~h}^{-1}$ (in 


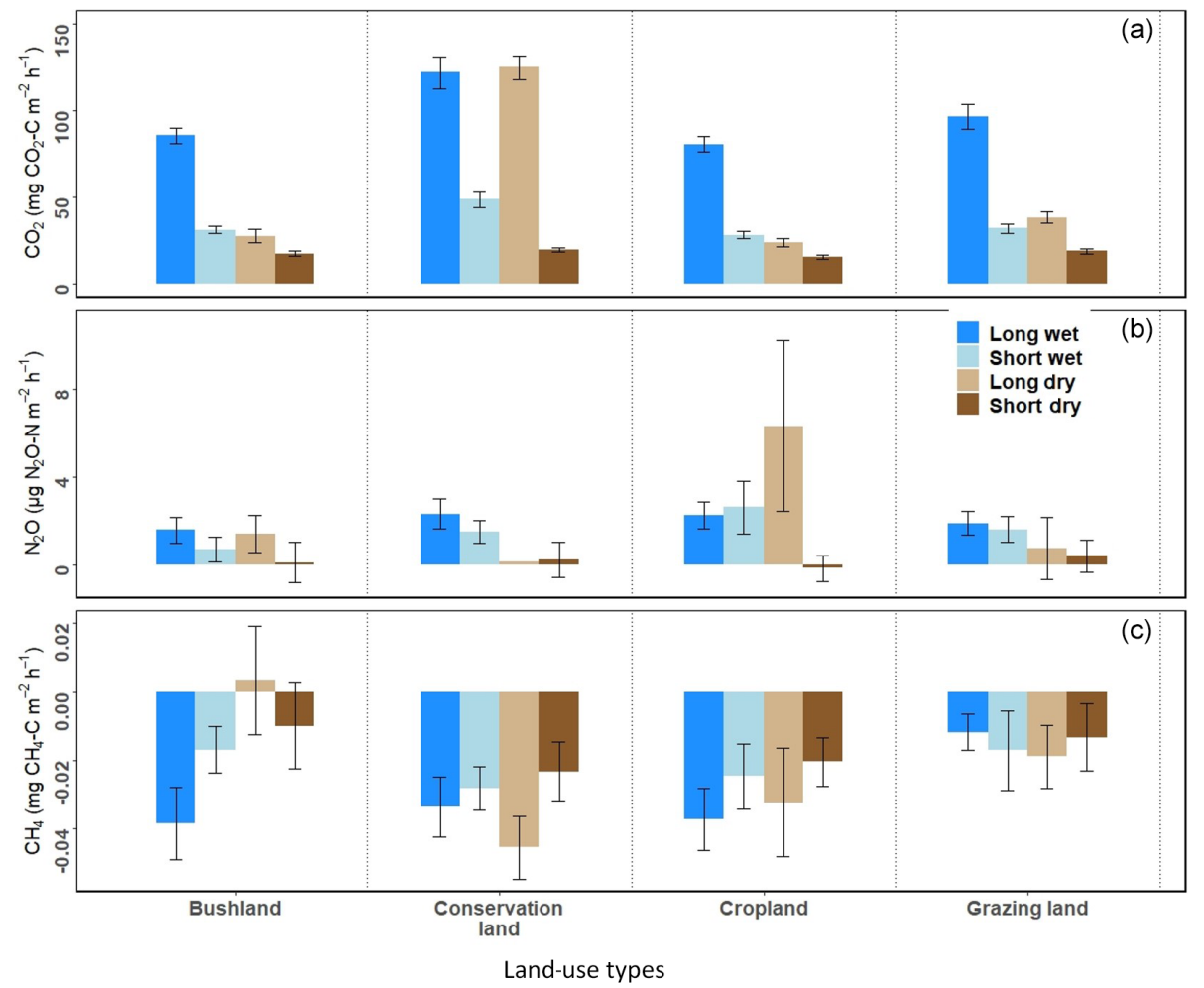

Figure 5. Seasonal differences in mean (a) $\mathrm{CO}_{2}$, (b) $\mathrm{N}_{2} \mathrm{O}$, and (c) $\mathrm{CH}_{4}$ emissions between the long and short wet seasons and the long and short dry seasons for the four land-use types.

grazing land on 4 September 2018). These were observed during the $\mathrm{SW}$ from chambers with animal droppings. For the dry seasons, $\mathrm{N}_{2} \mathrm{O}$ emissions did not differ between $\mathrm{SD}$ and LD in bushland, conservation land, and grazing land, while $\mathrm{N}_{2} \mathrm{O}$ emissions in cropland were significantly higher during the LD than they were during the SD (Fig. 5b).

\subsubsection{Soil methane $\left(\mathrm{CH}_{4}\right)$ emissions}

Throughout the study period, $\mathrm{CH}_{4}$ emissions did not vary significantly among sites and seasons (Figs. $4 \mathrm{e}$ and 5c). The studied sites were mostly $\mathrm{CH}_{4}$ sinks rather than sources, and $\mathrm{CH}_{4}$ fluxes were very low, ranging from -0.03 to $0.9 \mathrm{mg} \mathrm{CH}_{4}-\mathrm{C} \mathrm{m}^{-2} \mathrm{~h}^{-1}$ (Fig. 4e), often below the limit of detection $\left(0.03 \mathrm{mg} \mathrm{CH}_{4}-\mathrm{C} \mathrm{m}^{-2} \mathrm{~h}^{-1}\right)$.

\subsection{Effects of soil temperature, soil water content, and vegetation indices on soil GHG emissions}

Soil water content (WC) was highest during the wet season (mean $0.19 \pm 0.06 \mathrm{~m}^{3} \mathrm{~m}^{-3}$ ) and lowest during the dry season (mean. $0.07 \pm 0.02 \mathrm{~m}^{3} \mathrm{~m}^{-3}$ ) at all sites (see Fig. 4a). Soil temperature $(T)$ was highest during the $\mathrm{SD}\left(36.7 \pm 2.1^{\circ} \mathrm{C}\right)$ and lowest $\left(24.5 \pm 0.6^{\circ} \mathrm{C}\right)$ in the LD (Fig. 4b). Throughout all the campaigns, mean $\mathrm{WC}$ and mean $T$ were highest in conservation land, followed by grazing land and bushland, and lowest in cropland. Regression results on soil $\mathrm{CO}_{2}$ and soil $\mathrm{N}_{2} \mathrm{O}$ emissions against $T$ and $\mathrm{WC}$ are shown in Table 2 . The results showed positive correlations between soil $\mathrm{CO}_{2}$ emissions and WC $(p<0.05)$. However, $R^{2}$ was very weak at all sites. Conversely, $\mathrm{CO}_{2}$ emissions showed no correlation with $T(p<0.05)$. We observed no correlation between $\mathrm{N}_{2} \mathrm{O}$ and $\mathrm{CH}_{4}$ emissions with either WC or $T(p<0.05)$. Separating data into the wet and dry seasons did not improve the correlations.

Results from combined WC and $T$ on soil $\mathrm{CO}_{2}$ and $\mathrm{N}_{2} \mathrm{O}$ emissions did not improve the correlations, as shown in Table 3. Thus, we included vegetation indices in our model.

The annual change in vegetation cover at each site is shown in Fig. 6. The highest NDVI values were observed during the LW in April (ranging from 0.58 to 0.76) and the lowest were observed during the SD $(<0.26)$. Vegetation greenness increased rapidly from mid-March at all sites coinciding with the onset of the rainy season and remained high (Fig. 6). At the end of the rainy season, NDVI values gradually dropped. The highest NDVI values occurred in conservation land $(0.51 \pm 0.05)$, followed by bushland $(0.44 \pm 0.05)$ and cropland $(0.41 \pm 0.05)$, and the lowest were recorded in grazing land $(0.33 \pm 0.05)$.

Regression analysis results show a positive correlation between the NDVI and seasonal $\mathrm{CO}_{2}$ emissions at all the sites (see Fig. 7). Combined WC and NDVI values improved the correlation even further as shown in Table 4. No significant 
Table 2. Soil water content (WC) and soil temperature $(T)$ control on carbon dioxide $\left(\mathrm{CO}_{2}\right)$ and nitrous oxide $\left(\mathrm{N}_{2} \mathrm{O}\right)$, denoted by $R_{\mathrm{s}} ; a, b$, $c$, and $e$ denote the model coefficients.

\begin{tabular}{llrrrr}
\hline Predictors & Land use & \multicolumn{2}{c}{$\mathrm{CO}_{2}-\mathrm{C} \mathrm{mg} \mathrm{m}^{-2} \mathrm{~h}^{-1}$} & \multicolumn{2}{c}{$\mathrm{N}_{2} \mathrm{O}-\mathrm{N} \mu \mathrm{g} \mathrm{m}^{-2} \mathrm{~h}^{-1}$} \\
\hline Soil water content (WC) & Bushland & $6.12 \mathrm{WC}+0.92 \mathrm{WC}^{2}$ & $R^{2}=0.26^{* * *}$ & $19.02 \mathrm{WC}-64.11 \mathrm{WC}^{2}$ & $R^{2}=0.008$ \\
$R_{\mathrm{S}}=a+b \mathrm{WC}+c \mathrm{WC}^{2}$ & Conservation land & $135.27 \mathrm{WC}-0.57 \mathrm{WC}^{2}$ & $R^{2}=0.07^{* *}$ & $11.63 \mathrm{WC}-7.736 \mathrm{WC}^{2}$ & $R^{2}=0.009$ \\
& Cropland & $17.83 \mathrm{WC}+0.67 \mathrm{WC}^{2}$ & $R^{2}=0.04^{* * *}$ & $28.48 \mathrm{WC}-66.63 \mathrm{WC}^{2}$ & $R^{2}=0.005$ \\
& Grazing land & $15.03 \mathrm{WC}+0.79 \mathrm{WC}^{2}$ & $R^{2}=0.11^{* * *}$ & $19.81 \mathrm{WC}-53.56 \mathrm{WC}^{2}$ & $R^{2}=0.002$ \\
\hline Soil temperature $(T)$ & Bushland & $1.078 e^{0.26 T-0.004 T^{2}}$ & $R^{2}=0.008$ & $360.25 e^{-0.29 T-0.004 T^{2}}$ & $R^{2}=0.008$ \\
$R=a e^{\left(b T+c T^{2}\right)}$ & Conservation land & $0.001 e^{0.81 T-0.014 T^{2}}$ & $R^{2}=0.015^{* *}$ & $0.007 e^{0.45 T-0.008 T^{2}}$ & $R^{2}=0.015$ \\
& Cropland & $4.568 e^{-0.13 T+0.002 T^{2}}$ & $R^{2}=0.008^{*}$ & $0.007 e^{-0.05 T+2.42 T^{2}}$ & $R^{2}=0.008^{*}$ \\
& Grazing land & $4.136 e^{0.18 T-0.003 T^{2}}$ & $R^{2}=0.015$ & $2.366 e^{0.05 T-0.001 T^{2}}$ & $R^{2}=0.015$ \\
\hline
\end{tabular}

${ }^{* * *} p<0.0001{ }^{* *} p<0.001{ }^{*} p<0.05$.

Table 3. Combined effects of soil water content (WC) and soil temperature (T) control on soil $\mathrm{CO}_{2}$ and $\mathrm{N}_{2} \mathrm{O}$ emissions. Soil $\mathrm{CO}_{2}$ and $\mathrm{N}_{2} \mathrm{O}$ emissions are denoted by $R_{\mathrm{S}}$, while $a, b, d$, and $e$ signify the model coefficients, $R^{2}$ is the coefficient of determination, and AIC is the Akaike's information criterion.

\begin{tabular}{llrrrrrr}
\hline Functions & Land use & $a$ & $b$ & $d$ & $e$ & $R^{2}$ & AIC \\
\hline $\mathrm{CO}_{2}-\mathrm{C} \mathrm{mg} \mathrm{m}^{-2} \mathrm{~h}^{-1}$ & Bushland & -0.12 & 0.001 & 52.774 & -0.527 & $0.31^{* * *}$ & 1888 \\
$R_{\mathrm{S}}=e^{\left(a T+b T^{2}\right)} \times\left(d \mathrm{WC}+e \mathrm{WC}^{2}\right)$ & Conservation land & 0.90 & -0.016 & 0.0001 & 0.000 & $0.10^{* * *}$ & 2156 \\
& Cropland & -0.39 & 0.006 & 3701.901 & -84.001 & $0.08^{* *}$ & 1886 \\
& Grazing land & 0.14 & -0.003 & 0.842 & -0.008 & $0.12^{* * *}$ & 2024 \\
\hline $\mathrm{N}_{2} \mathrm{O}-\mathrm{N} \mathrm{\mu g} \mathrm{m}^{-2} \mathrm{~h}^{-1}$ & Bushland & -0.50 & 0.007 & 2008.345 & -58.559 & 0.009 & 785 \\
$R_{\mathrm{S}}=e^{\left(a T+b T^{2}\right)} \times\left(d \mathrm{WC}+e \mathrm{WC}^{2}\right)$ & Conservation land & 0.56 & -0.010 & 0.000 & 0.000 & 0.003 & 811 \\
& Cropland & 0.67 & -0.017 & 0.003 & -0.0001 & 0.089 & 911 \\
& Grazing land & 0.11 & -0.003 & 0.187 & -0.005 & 0.003 & 770 \\
\hline
\end{tabular}

${ }^{* * *} p<0.0001 .{ }^{* *} p<0.001 .{ }^{*} p<0.05$.

correlation was observed between $\mathrm{N}_{2} \mathrm{O}$ emissions and the NDVI (Fig. 7).

\section{Discussion}

\subsection{Soil $\mathrm{CO}_{2}$ emissions}

Soil $\mathrm{CO}_{2}$ emissions differed significantly between the four LUTs. The highest mean $\mathrm{CO}_{2}$ emissions were observed in conservation land followed by grazing land and bushland, and the lowest were from cropland. Soil C content, which is the primary source of energy for soil microorganisms that contribute to soil $\mathrm{CO}_{2}$ emissions (Lal, 2009), also showed the same trend (conservation land $>$ grazing land $>$ bushland $>$ cropland). Therefore, the differences in land use and land-use management activities between our sites played a vital role in modifying both biotic and abiotic factors that drive both soil $\mathrm{C}$ content and soil $\mathrm{CO}_{2}$ emissions (Pinto et al., 2002).

Due to the differences in land use and management, vegetation type and cover differed between our sites. The dense grass network in conservation land formed an almost closed ground cover, especially in the wet seasons (further confirmed by NDVI values). Being a private sanctuary, only wild mammals (no livestock allowed) grazed and browsed there, and thus we observed less damage on the grass cover throughout all the campaigns as compared to grazing land (which had large patches of bare soil due to overgrazing) and bushland. This provides a good explanation for the difference in mean $\mathrm{CO}_{2}$ emissions between these three LUTs, as vegetation is known to affect soil $\mathrm{C}$ concentration and root and microbial respiration that directly contribute to soil $\mathrm{CO}_{2}$ emissions (Fanin et al., 2011; Rey et al., 2011).

With the lowest $\mathrm{CO}_{2}$ emissions being measured in cropland, we attribute this observation to the continued tillage and removal of crops and crop residues during land preparation, weeding, and harvesting, which affect both root respiration and soil C content (Raich et al., 2000; Nandwa, 2001). In east Africa and especially in smallholder farming systems, most of the crop residues are used as livestock feed and fuel. In addition, manure inputs in cropland are very low (about $20 \mathrm{~kg}$ per month on a $1.5 \mathrm{ha}$ farm), and thus no measurable 


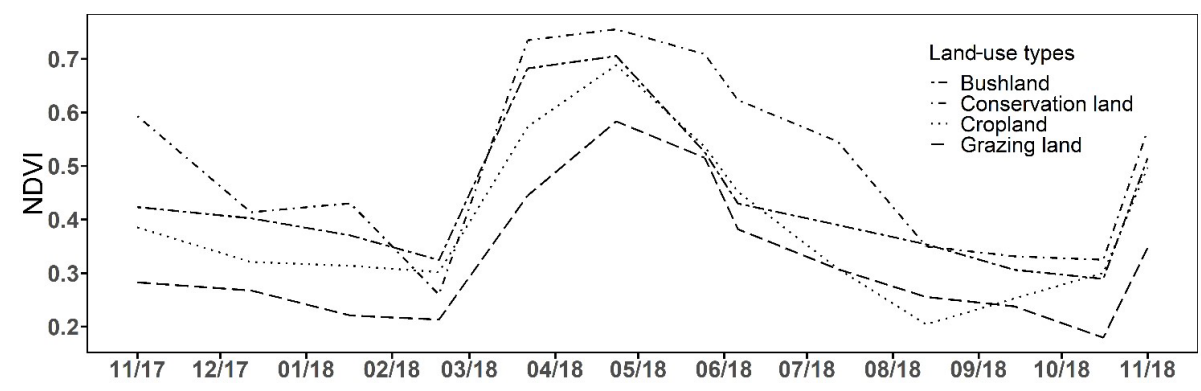

Figure 6. Monthly NDVI time series showing the annual trend in vegetation cover from November 2017 to November 2018 for the four land-use types. (See Fig. S1 in the Supplement for the change in the normalized difference vegetation index (NDVI) during each campaign.)
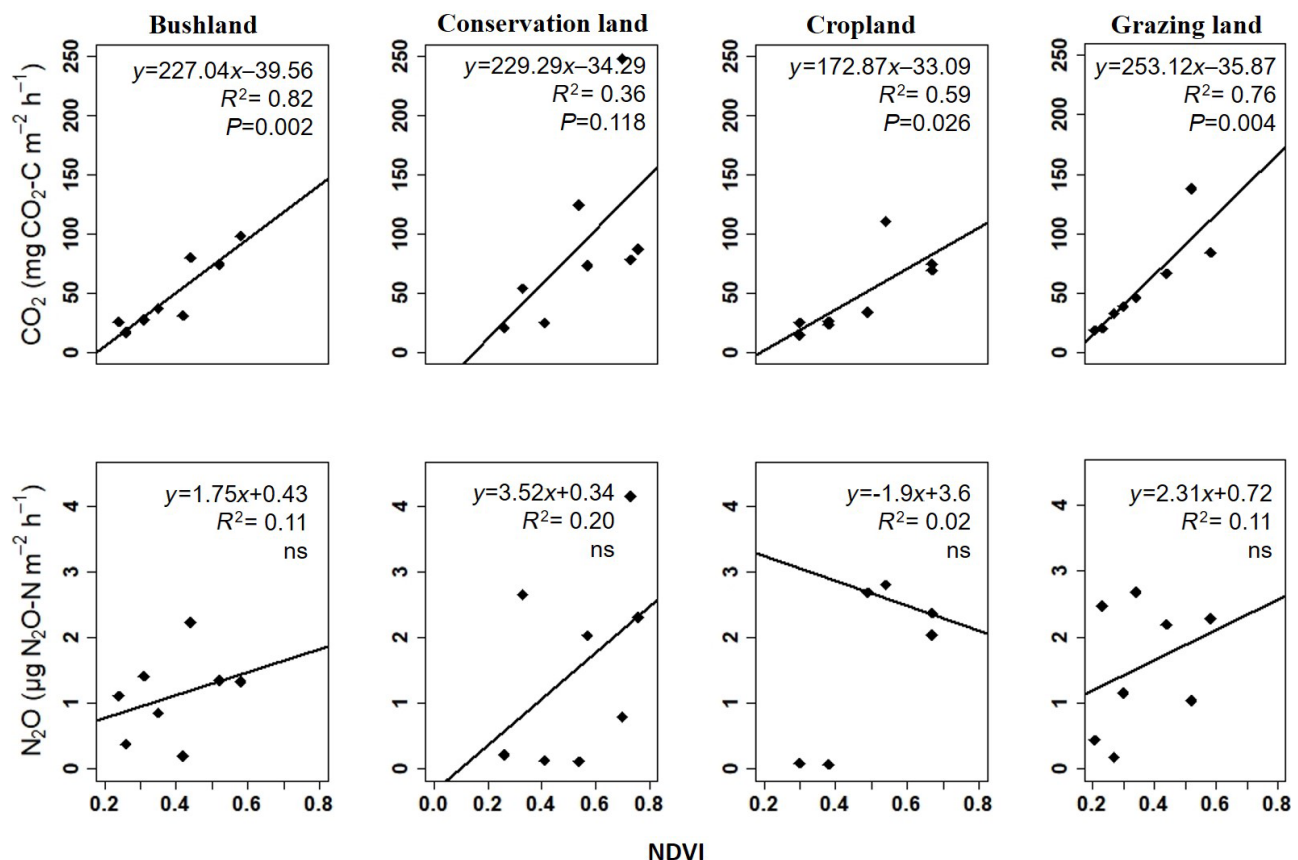

Figure 7. Linear regression analyses of the measured seasonal means for soil $\mathrm{CO}_{2}$ and soil $\mathrm{N}_{2} \mathrm{O}$ emissions during the campaign from November 2017 to November 2018 plotted against NDVI data acquired during each campaign; ns = not significant.

difference in $\mathrm{CO}_{2}$ emissions was detected before and after manure input and with the other LUTs. Several other studies observed the same scenario from low manure input in maize and sorghum plots (Rosenstock et al., 2016; Mapanda et al., 2011; Pelster et al., 2017).

On average, $\mathrm{CO}_{2}$ emissions were higher during the wet season than during the dry season. At the start of both rainy seasons ( $\mathrm{SW}, \mathrm{LW}), \mathrm{CO}_{2}$ emissions increased significantly in all LUTs. Emissions from conservation land and grazing land are comparable to those in Brümmer et al. (2008), who observed $\mathrm{CO}_{2}$ emissions ranging between 100 and $250 \mathrm{mg} \mathrm{CO}_{2}-\mathrm{C} \mathrm{m}^{-2} \mathrm{~h}^{-1}$ in a natural savanna in Burkina Faso. Several other studies from similar ecosystems have also documented comparable changes in $\mathrm{CO}_{2}$ emissions with the onset of the rainy seasons (Castaldi et al., 2006; Livesley et al., 2011; Pinto et al., 2002). In cropland, results in the wet season are similar to those measured by Rosenstock et al. (2016), ranging from 50 to $>200 \mathrm{mg} \mathrm{m}^{-2} \mathrm{~h}^{-1}$. We attributed the increase in $\mathrm{CO}_{2}$ emissions in the wet season to the response of soil microbes and vegetation to soil moisture (Livesley et al., 2011; Otieno et al., 2010). Soil moisture connects microorganisms with soluble substrates (Moyano et al., 2013) and increases microbial activity (Davidson and Janssens, 2006; Davidson, 2009; Grover et al., 2012) and thereby soil $\mathrm{CO}_{2}$ emissions.

Furthermore, an increase in soil $\mathrm{CO}_{2}$ emissions during the wet season can also be a result of increased root respiration due to more active plant and root growth (Macdonald et al., 2006). Grasses sprout more rapidly than trees and shrubs with the first rains (Merbold et al., 2009). This provides a possible explanation for the higher $\mathrm{CO}_{2}$ emissions in grassy conservation land, grazing land, and bushland com- 
Table 4. Combined effects of soil water content (WC) and the NDVI on soil $\mathrm{CO}_{2}$ emissions. Soil $\mathrm{CO}_{2}$ emissions denoted by $R_{\mathrm{S}}$, while $a, b$, $c$, and $d$ are the model coefficients and $\left(R^{2}\right)$ is the coefficient of determination.

\begin{tabular}{llrrrrr}
\hline & Land use & $a$ & $b$ & $c$ & $d$ & $R^{2}$ \\
\hline $\mathrm{CO}_{2}-\mathrm{C} \mathrm{mg} \mathrm{m}^{-2} \mathrm{~h}^{-1}$ & Bushland & -29.69 & 196.47 & -83.74 & 781.29 & $0.86^{* * *}$ \\
$R_{\mathrm{S}}=a+b \mathrm{NDVI}+\left(c \mathrm{WC}+d \mathrm{WC}^{2}\right)$ & Conservation land & 6.48 & 382.96 & -861.98 & -256.66 & $0.82^{* * *}$ \\
& Cropland & 26.94 & 244.54 & -1250.22 & 3269.46 & $0.79^{* * *}$ \\
& Grazing land & -97.19 & 396.41 & 575.60 & -3440.80 & $0.96^{* * *}$ \\
\hline
\end{tabular}

*** $p<0.0001,{ }^{* *} p<0.001,{ }^{*} p<0.05$.

pared to cropland during the rainy season. However, grazing land recorded higher $\mathrm{CO}_{2}$ emissions than bushland (only the farmer's livestock grazed here). The main difference between these two sites - apart from grazing intensity - was that bushland had more trees (Acacia spp.) and shrubs (Commiphora spp.) and less herbaceous undergrowth than grazing land, thus providing shade that might have interfered with growth and regrowth of plants below the canopy. Therefore, grass root production in open conservation land and grazing land was likely higher than in bushland (Janssens et al., 2001), although we cannot confirm this because root biomass was not determined in this study. In cropland, all grasses and weeds were cleared during regular weeding and therefore did not play a role in root respiration.

To our surprise, the highest mean seasonal $\mathrm{CO}_{2}$ emissions in conservation land, grazing land, and cropland were observed at the end rather than at the peak of the wet season. During this time, both soil moisture and soil temperature had dropped in all LUTs. However, our data were only recorded up to a depth of $5 \mathrm{~cm}$, but roots of perennial grasses, shrubs, and trees can tap moisture from greater soil depths (Carbone et al., 2011). According to Carbone et al. (2011), while microbial activity is highest and most variable in the upper soil layers, which are first to wet up and dry down, roots can access water reserves in deeper soil layers that take longer to be exhausted and therefore remain active at the end of the wet and into the dry season.

\subsection{Soil $\mathrm{N}_{2} \mathrm{O}$ emissions}

Our results showed very low $\mathrm{N}_{2} \mathrm{O}$ emissions from all LUTs, which we attributed to low soil $\mathrm{N}$ content observed in all the sites (see Table 1). Savanna ecosystems are characterized by very tight $\mathrm{N}$ cycling, which translates into low $\mathrm{N}$ availability (Pinto et al., 2002; Grover et al., 2012), and most of this $\mathrm{N}$ is rapidly taken up by vegetation, leaving very little for denitrification (Castaldi et al., 2006; Mapanda et al., 2011). The $\mathrm{N}_{2} \mathrm{O}$ flux results observed from conservation land, grazing land, and bushland are consistent with those observed in a Brazilian savanna by Wilcke and Lilienfein (2005), and other studies from similar ecosystems have reported comparable $\mathrm{N}_{2} \mathrm{O}$ flux magnitudes (Scholes et al., 1997; Castaldi et al., 2006; Mapanda et al., 2010). The higher $\mathrm{N}_{2} \mathrm{O}$ emissions ob- served in June and July from our cropland site after the maize and bean harvests likely occurred due to the disturbance and following absence of live plants, which led to higher soil $\mathrm{N}$ availability because of less $\mathrm{N}$ uptake by plants and increased root decomposition.

In contrast to the patterns observed for $\mathrm{CO}_{2}$ emissions, we did not detect any seasonal variations in $\mathrm{N}_{2} \mathrm{O}$ emissions. The only exception to the otherwise very low $\mathrm{N}_{2} \mathrm{O}$ emissions was after the onset of the rainy season, when $\mathrm{N}_{2} \mathrm{O}$ emissions slightly increased at all sites. Such patterns have previously been shown by several similar studies (Scholes et al., 1997; Pinto et al., 2002; Castaldi et al., 2006; Livesley et al., 2011). The increase in $\mathrm{N}_{2} \mathrm{O}$ flux at the onset of the rains has been attributed to an increase in microbial activity and therefore faster decomposition of litter and plant residue facilitated by an increase in soil moisture, thus increasing $\mathrm{N}$ availability (Rees et al., 2006). Furthermore, according to Davidson et al. (2000) and Butterbach-Bahl et al. (2013), soil moisture affects soil gas diffusion, oxygen $\left(\mathrm{O}_{2}\right)$ availability, and the movement of substrate necessary for microbial growth and metabolism.

Negative $\mathrm{N}_{2} \mathrm{O}$ emissions were detected during the dry season. Such observations could result from the low N content observed at all sites coupled with low soil moisture in the dry season, which facilitates diffusion of atmospheric $\mathrm{N}_{2} \mathrm{O}$ into the soil. Soil denitrifiers may, therefore, use $\mathrm{N}_{2} \mathrm{O}$ as an $\mathrm{N}$ substrate in the absence of $\mathrm{NO}_{2}^{-}$and $\mathrm{NO}_{3}^{-}$(Rosenkranz et al., 2006). Negative $\mathrm{N}_{2} \mathrm{O}$ emissions have also been reported in other tropical savanna soils under similarly dry conditions (Castaldi et al., 2006; Livesley et al., 2011).

Manure application in cropland was very low $(<12 \mathrm{~kg}$ of $\mathrm{N}$ in 1.5 ha for the crop-growing season), and thus $\mathrm{N}_{2} \mathrm{O}$ emissions from cropland were low and not different from the other LUTs, which was in contrast to what we had hypothesized. Due to low soil $\mathrm{N}$ levels in cropland, the low amount of manure added was not sufficient to stimulate $\mathrm{N}_{2} \mathrm{O}$ emissions, likely because soil $\mathrm{N}$ availability was still limiting for plant and microbial growth (Castaldi et al., 2006). Traditional farming systems in smallholder farms in Africa involve repeated cropping with no or very low $\mathrm{N}$ inputs that leads to soil $\mathrm{N}$ mining over time (Chianu et al., 2012). In line with this, in our cropland site maize and beans are grown during every wet season with no fallow years. In addition, the 
farmer did not use any chemical fertilizer to increase soil $\mathrm{N}$, and the $\mathrm{N}$ input from biological $\mathrm{N}$ fixation into the soil was likely small because beans were harvested for consumption and bean plant residues were used as livestock feed and not incorporated into the soil. Therefore, the small quantities of manure applied and legume $\mathrm{N}$ fixation may likely have been insufficient to compensate for $\mathrm{N}$ loss through leaching and crop harvests. According to the Taita development plan, this is a common scenario in the county, which translates to very low crop yields in this region (CIDP, 2014). Another possible explanation for not detecting the influence of manure on $\mathrm{N}_{2} \mathrm{O}$ emissions could be the fact that we did not manage to sample immediately after manure application and therefore might have missed the instant impact of manure application on $\mathrm{N}_{2} \mathrm{O}$ emissions. However, similar studies by Pelster et al. (2017) and Rosenstock et al. (2016) also did not see any influence of manure application on soil $\mathrm{N}_{2} \mathrm{O}$ emissions and reported $\mathrm{N}_{2} \mathrm{O}$ emission values that were generally $<10 \mu \mathrm{g} \mathrm{N} \mathrm{N}_{2} \mathrm{O}-\mathrm{N} \mathrm{m}^{-2} \mathrm{~h}^{-1}$. Equally, the deposition of dung and urine by animals in the grazing land and bushland did not have any measurable influence on soil $\mathrm{N}_{2} \mathrm{O}$ emissions.

\subsection{Soil $\mathrm{CH}_{4}$ emissions}

Methane emissions did not vary between the land-use types or with seasons. Most values were below the LOD at all the sites. Soil water content in our study is clearly the limiting factor for methanogenesis, which needs anoxic conditions for a certain period until methanogenic archaea are established (Serrano-Silva et al., 2014). Furthermore, soil compaction by animal trampling may have limited $\mathrm{CH}_{4}$ diffusion into the soil, thus limiting $\mathrm{CH}_{4}$ consumption by oxidation (Ball et al., 1997). In cropland, continuous tillage interferes with soil structure, thus affecting the microenvironment that favours methanotrophs (Jacinthe et al., 2014). Additionally, low soil $\mathrm{C}$ as observed in all the sites generally leads to low abundance of soil microorganisms and consequently also methane oxidizers (Serrano-Silva et al., 2014). Nevertheless, soils around lakes, waterholes, and rivers can be $\mathrm{CH}_{4}$ sources in semi-arid savanna ecosystems, but those were not investigated during this study.

\subsection{Effects of soil moisture, soil temperature, and vegetation indices on GHG emissions}

As is common for subtropical regions, seasonal variation in soil temperature was small in the study region, and therefore soil temperature did not play a big role in modifying soil GHG emissions. Instead, changes in soil moisture were considered to be the main driver of $\mathrm{CO}_{2}$ emissions in our study, as has previously also been highlighted by other studies (Grover et al., 2012; Brümmer et al., 2009; Livesley et al., 2011). However, we did not observe any significant relationship between $\mathrm{N}_{2} \mathrm{O}$ emissions and either soil moisture or tem- perature apart from in cropland, where we found a positive correlation between $\mathrm{N}_{2} \mathrm{O}$ and soil temperature $(p<0.05)$. As much as previous results have sometimes shown a positive relationship between temperature and $\mathrm{N}_{2} \mathrm{O}$ emissions (Castaldi et al., 2010), our results are in line with others (Scholes et al., 1997; Brümmer et al., 2008) who were also unable to link soil $\mathrm{N}_{2} \mathrm{O}$ emissions to variations in soil temperature. In fact, $\mathrm{N}_{2} \mathrm{O}$ emissions were very low during both the wet and dry seasons, which is similar to the findings of Castaldi et al. (2004). The most likely explanation for the lack of seasonality effects on $\mathrm{N}_{2} \mathrm{O}$ emissions would be the low soil $\mathrm{N}$ levels observed at all the sites, which was probably the most limiting factor for $\mathrm{N}_{2} \mathrm{O}$ emissions and thus overruled all other potential controlling factors (Grover et al., 2012).

The vegetation cover as depicted by the NDVI shows the status of the vegetation (NDVI values range from +1.0 to $-1.0)$. High NDVI values correspond to high vegetation cover, while low NDVI values correspond to little or no vegetation (Gamon et al., 1995; Butt et al., 2011). Therefore, the increase in NDVI values that we observed at the onset of the rainy season indicates sprouting and regrowth of vegetation at that time, while the drop in NDVI values at the end of the rainy season indicates reduction in vegetation cover due to plant senescence and grazing. In cropland area, low NDVI values coincided with the harvesting of beans and the drying of the maize plants in June and July. The highest mean NDVI values were observed in conservation land, mainly due to the dense grassy vegetation, while the lowest NDVI values were found in grazing land, which we had expected because this area has large spots without vegetation due to overgrazing. Results from linear regression analysis showed a strong positive correlation of soil $\mathrm{CO}_{2}$ emissions with NDVI values $(p<0.05)$, explaining between $35 \%$ and $82 \%$ of the variation in soil $\mathrm{CO}_{2}$ emissions at the four sites. This means that $\mathrm{CO}_{2}$ emissions were highest when the NDVI (i.e. vegetation cover) was high. Thus, the inclusion of both the NDVI and soil moisture measurements is essential for reliably predicting soil $\mathrm{CO}_{2}$ emissions from savanna soils, which is consistent with other studies (Reichstein et al., 2003; Anderson et al., 2008; Lees et al., 2018). Concurrently, the same relationship between the NDVI and $\mathrm{N}_{2} \mathrm{O}$ emissions could not be proven in our study.

\section{Conclusion}

The magnitude and temporal and spatial variability in soil GHG emissions in most developing countries have large uncertainties due to a lack of data, especially in dry areas and ecosystems facing land-use change. In our study, we quantified soil GHG emissions from four dominant LUTs in the dry lowlands of southern Kenya, namely bushland, conservation land, cropland, and grazing land. Our results showed significant variation between seasons and the respective LUTs. $\mathrm{CO}_{2}$ 
emissions, in particular, were higher during the wet season, when soil moisture was high, compared to the dry season. Most of the variation in $\mathrm{CO}_{2}$ emissions could be explained by soil moisture and the NDVI, highlighting the importance of including proxies for vegetation cover in soil GHG emission studies in savannas. $\mathrm{N}_{2} \mathrm{O}$ emissions and $\mathrm{CH}_{4}$ emissions were of minor importance at all sites. However, we acknowledge that we might have missed some episodes of elevated soil $\mathrm{N}_{2} \mathrm{O}$ emissions, as these are often episodic and of short duration, for example after fertilization or precipitation events. Following these results, there is still a need for more continuous studies to cover spatial and temporal variation in soil GHG emissions as well as a need for the inclusion of LUTs other than the ones examined in this study (e.g. wetlands). Nevertheless, we believe that our results are important to reduce uncertainties in GHG emission baselines and to identify reliable and meaningful climate change mitigation interventions by informing the relevant policies.

Data availability. The data associated with the paper can be obtained from https://figshare.com/articles/Final_data_for_Soil_ Greenhouse_Gas_Emissions_under_Different_Land-Use_Types_ in_Savanna_Ecosystems_of_Kenya_/11673579 (Wachiye et al., 2020).

Supplement. The supplement related to this article is available online at: https://doi.org/10.5194/bg-17-2149-2020-supplement.

Author contributions. SW, PP, and LM developed and designed the experiments for this study. SW and PP executed the experiments. SW, LM, and SL analyzed the data. SW, LM, and PP contributed materials and analysis tools. SW wrote the manuscript with major comments from LM, SL, PP, TV, JR, and MR.

Competing interests. The authors declare that they have no conflict of interest.

Acknowledgements. We acknowledge the Taita Research Station of the University of Helsinki for technical and fieldwork support and Mazingira Centre of the International Livestock Research Institute for technical support in the laboratory work. Specifically, we would like to thank Mwadime Mjomba for his help in field data collection and Paul Mutua, George Wanyama, Sheila Okoma, Francis Njenga, and Margaret Philip for their help with the laboratory work. We acknowledge the Taita Hills Wildlife Sanctuary and LUMO Community Wildlife Sanctuary for providing us with access to the sanctuaries and especially Richard Obanda and Donart Mwambela Mwakio and the team of wardens for accompanying us when needed.

Financial support. This research has been funded by the Schlumberger Foundation Faculty for the Future program (grant no.
4720995). The work was conducted under the environmental sensing of ecosystem services for developing a climate-smart landscape framework to improve food security in East Africa, funded by the Academy of Finland (grant no. 318645). A research permit from NACOSTI (grant no. P/18/97336/26355) is acknowledged. Lutz Merbold and Sonja Leitner acknowledge the support provided by the CGIAR Fund Council, Australia (ACIAR), Irish Aid, the European Union, the International Fund for Agricultural Development (IFAD), the Netherlands, New Zealand, United Kingdom, USAID, and the Kingdom of Thailand for funding the CGIAR Research Program on Livestock. Janne Rinne and Lutz Merbold were further supported by the European Commission through the project, Supporting EU-African Cooperation on Research Infrastructures for Food Security and Greenhouse Gas Observations (H2020 Research Infrastructures, SEACRIFOG (grant no. 730995)).

Open-access funding provided by Helsinki University Library.

Review statement. This paper was edited by Paul Stoy and reviewed by Dennis Otieno and two anonymous referees.

\section{References}

Abdalla, M., Hastings, A., Chadwick, D. R., Jones, D. L., Evans, C. D., Jones, M. B., Rees, R. M., and Smith, P.: Critical Review of the Impacts of Grazing Intensity on Soil Organic Carbon Storage and Other Soil Quality Indicators in Extensively Managed Grasslands, Agr. Ecosyst. Environ., 253, 62-81, https://doi.org/10.1016/j.agee.2017.10.023, 2018.

Anderson, M. C., Norman, J. M., Kustas, W. P., Houborg, R., Starks, P. J., and Agam, N.: A Thermal-Based Remote Sensing Technique for Routine Mapping of LandSurface Carbon, Water and Energy Fluxes from Field to Regional Scales, Remote Sens. Environ., 112, 4227-4241, https://doi.org/10.1016/j.rse.2008.07.009, 2008.

Ardö, J., Mölder, M., El-Tahir, B. A., and Mohammed Elkhidir, H. A.: Seasonal Variation of Carbon Fluxes in a Sparse Savanna in Semi-Arid Sudan, Carbon Balance and Management, 3, 7, https://doi.org/10.1186/1750-0680-3-7, 2008.

Arias-Navarro, C., Díaz-Pinés, E., Kiese, R., Rosenstock, T. S., Rufino, M. C., Stern, D., Neufeldt, H., Verchot, L. V., and Butterbach-Bahl, K.: Gas Pooling: A Sampling Technique to Overcome Spatial Heterogeneity of Soil Carbon Dioxide and Nitrous Oxide Fluxes, Soil Biol. Biochem., 67, 20-23, https://doi.org/10.1016/j.soilbio.2013.08.011, 2013.

Arrhenius, S.: On the Influence of Carbonic Acid in the Air upon the Temperature of the Ground, The London, Edinburgh, and Dublin Philosophical Magazine and Journal of Science, 41, 237-276, https://doi.org/10.1080/14786449608620846, 1896.

Ball, B. C., Dobbie, K. E., Parker, J. P., and Smith, K. A.: The Influence of Gas Transport and Porosity on Methane Oxidation in Soils, J. Geophys. Res.-Atmos., 102, 23301-23308, https://doi.org/10.1029/97JD00870, 1997.

Bombelli, A., Henry, M., Castaldi, S., Adu-Bredu, S., Arneth, A., de Grandcourt, A., Grieco, E., Kutsch, W. L., Lehsten, V., Rasile, A., Reichstein, M., Tansey, K., Weber, U., and Valentini, R.: An outlook on the Sub-Saharan Africa carbon balance, Bio- 
geosciences, 6, 2193-2205, https://doi.org/10.5194/bg-6-21932009, 2009.

Brink, A. B. and Eva, H. D.: Monitoring 25 Years of Land Cover Change Dynamics in Africa: A Sample Based Remote Sensing Approach, Appl. Geogr., 29, 501-512, https://doi.org/10.1016/j.apgeog.2008.10.004, 2009.

Brink, A. B., Bodart, C., Brodsky, L., Defourney, P., Ernst, C., Donney, F., Lupi, A., and Tuckova, K.: Anthropogenic Pressure in East Africa - Monitoring 20 Years of Land Cover Changes by Means of Medium Resolution Satellite Data, Int. J. Appl. Earth Obs., 28, 60-69, https://doi.org/10.1016/j.jag.2013.11.006, 2014.

Brümmer, C., Brüggemann, N., Butterbach-Bahl, K., Falk, U., Szarzynski, J., Vielhauer, K., Wassmann, R., and Papen, H.: SoilAtmosphere Exchange of $\mathrm{N}_{2} \mathrm{O}$ and $\mathrm{NO}$ in Near-Natural Savanna and Agricultural Land in Burkina Faso (W. Africa), Ecosystems, 11, 582-600, https://doi.org/10.1007/s10021-008-9144-1, 2008.

Brümmer, C., Papen, H., Wassmann, R., and Brüggemann, N.: Fluxes of $\mathrm{CH}_{4}$ and $\mathrm{CO}_{2}$ from Soil and Termite Mounds in South Sudanian Savanna of Burkina Faso (West Africa), Global Biogeochem. Cy., 23, GB1001, https://doi.org/10.1029/2008GB003237, 2009.

Burke, S. D., Quinn, K. J., and Chen, V. J.: Synthesis of a $\mathrm{C}_{22}-\mathrm{C}_{34}$ Halichondrin B Precursor via Ring Opening-Double Ring Closing Metathesis, J. Org. Chem., 63, 8626-8627, https://doi.org/10.1021/jo981342e, 1998.

Butt, B., Turner, M. D., Singh, A., and Brottem, L.: Use of MODIS NDVI to Evaluate Changing Latitudinal Gradients of Rangeland Phenology in Sudano-Sahelian West Africa, Remote Sens. Environ., 115, 3367-3376, https://doi.org/10.1016/j.rse.2011.08.001, 2011.

Butterbach-Bahl, K., Breuer, L., Gasche, R., Willibald, G., and Papen, H.: Exchange of Trace Gases between Soils and the Atmosphere in Scots Pine Forest Ecosystems of the Northeastern German Lowlands: 1 . Fluxes of $\mathrm{N}_{2} \mathrm{O}, \mathrm{NO} / \mathrm{NO}_{2}$ and $\mathrm{CH}_{4}$ at Forest Sites with Different N-Deposition, Forest Ecol. Manag., 167, 123-134, https://doi.org/10.1016/S0378-1127(01)00725-3, 2002.

Butterbach-Bahl, K., Baggs, E. M., Dannenmann, M., Kiese, R., and Zechmeister-Boltenstern, S.: Nitrous Oxide Emissions from Soils: How Well Do We Understand the Processes and Their Controls?, Philos. T. R. Soc. B, 368, 1621, https://doi.org/10.1098/rstb.2013.0122, 2013.

Carbone, M. S., Winston, G. C., and Trumbore, S. E.: Soil Respiration in Perennial Grass and Shrub Ecosystems: Linking Environmental Controls with Plant and Microbial Sources on Seasonal and Diel Timescales, J. Geophys. Res.-Biogeo., 113, G02022, https://doi.org/10.1029/2007JG000611, 2008.

Carbone, M. S., Still, C. J., Ambrose, A. R., Dawson, T. E., Williams, A. P., Boot, C. M., Schaeffer, S. M., and Schimel, J. P.: Seasonal and Episodic Moisture Controls on Plant and Microbial Contributions to Soil Respiration, Oecologia, 167, 265-278, 2011.

Castaldi, S., De Pascale, R. A., Grace, J., Nikonova, N., Montes, R., and San José, J.: Nitrous Oxide and Methane Fluxes from Soils of the Orinoco Savanna under Different Land Uses, Glob. Change Biol., 10, 1947-1960, https://doi.org/10.1111/j.13652486.2004.00871.x, 2004.
Castaldi, S., Ermice, A., and Strumia, S.: Fluxes of $\mathrm{N}_{2} \mathrm{O}$ and $\mathrm{CH}_{4}$ from Soils of Savannas and Seasonally-Dry Ecosystems, J. Biogeogr., 33, 401-415, https://doi.org/10.1111/j.13652699.2005.01447.x, 2006.

Castaldi, S., de Grandcourt, A., Rasile, A., Skiba, U., and Valentini, R.: $\mathrm{CO}_{2}, \mathrm{CH}_{4}$ and $\mathrm{N}_{2} \mathrm{O}$ fluxes from soil of a burned grassland in Central Africa, Biogeosciences, 7, 3459-3471, https://doi.org/10.5194/bg-7-3459-2010, 2010.

Chapuis-Lardy, L., Wrage, N., Metay, A., Chotte, J.-J., and Bernoux, M.: Soils, a Sink for $\mathrm{N}_{2} \mathrm{O}$ ? A Review, Glob. Change Biol., 13, 1-17, https://doi.org/10.1111/j.13652486.2006.01280.x, 2007.

Chianu, J. N., Chianu, J. N., and Mairura, F.: Mineral Fertilizers in the Farming Systems of Sub-Saharan Africa. A Review, Agron. Sustain. Dev., 32, 545-566, https://doi.org/10.1007/s13593-0110050-0, 2012.

CIDP: Supporting Quality Life for the People of Taita Taveta, The First Taita Taveta County Integrated Development Plan 20132017, available at: https://ke.boell.org/sites/default/files/uploads/ 2014/05/revised_draft_cidp_30_april_2014_2.pdf (last access: 29 November 2018), 2014.

Collier, S. M., Ruark, M. D., Oates, L. G., Jokela, W. E., and Dell, C. J.: Measurement of Greenhouse Gas Flux from Agricultural Soils Using Static Chambers, JOVE-J. Vis. Exp., 90, e52110, https://doi.org/10.3791/52110, 2014.

Croghan, W. and Egeghy, P. P.: Methods of Dealing with Values Below the Limit of Detection using SAS, Southern SAS User Group, 22-24 September 2003, St. Petersburg, FL, available at: http://analytics.ncsu.edu/sesug/2003/SD08-Croghan.pdf (last access: 22 September 2019), 2003.

Davidson, E. A.: The Contribution of Manure and Fertilizer Nitrogen to Atmospheric Nitrous Oxide since 1860, Nat. Geosci., 2, 659-662, https://doi.org/10.1038/ngeo608, 2009.

Davidson, E. A. and Janssens, I. A.: Temperature Sensitivity of Soil Carbon Decomposition and Feedbacks to Climate Change, Nature, 440, 165-173, https://doi.org/10.1038/nature04514, 2006.

Davidson, E. A., Keller, M., Erickson, H. E., Verchot, L. V., and Veldkamp, E.: Testing a Conceptual Model of Soil Emissions of Nitrous and Nitric OxidesUsing Two Functions Based on Soil Nitrogen Availability and Soil Water Content, the Hole-inthe-Pipe Model Characterizes a Large Fraction of the Observed Variation of Nitric Oxide and Nitrous Oxide Emissions from Soils, BioScience, 50, 667-680, https://doi.org/10.1641/00063568(2000)050[0667:TACMOS]2.0.CO;2, 2000.

Didan, K.: MOD13Q1 MODIS/Terra Vegetation Indices 16-Day L3 Global $250 \mathrm{~m}$ SIN Grid V006, distributed by NASA EOSDIS Land Processes DAAC, https://doi.org/10.5067/MODIS/MOD13Q1.006, 2015.

ESA (European Spatial Agency): Sentinel-2 user handbook, ESA Standard Document, 64 pp., 2015.

Fanin, N., Hättenschwiler, S., Barantal, S., Schimann, H., and Fromin, N.: Does Variability in Litter Quality Determine Soil Microbial Respiration in an Amazonian Rainforest?, Soil Biol. Biochem., 43, 1014-1022, https://doi.org/10.1016/j.soilbio.2011.01.018, 2011.

FAO: Agro-Ecological Zoning Guidelines, FAO Soils Bulletin 76, available at: https://www.mpl.ird.fr/crea/taller-colombia/FAO/ AGLL/pdfdocs/aeze.pdf (last access: 4 March 2019), 1996. 
Flechard, C. R., Neftel, A., Jocher, M., Ammann, C., and Fuhrer, J.: Bi-Directional Soil/Atmosphere $\mathrm{N}_{2} \mathrm{O}$ Exchange over Two Mown Grassland Systems with Contrasting Management Practices, Glob. Change Biol., 11, 2114-2127, https://doi.org/10.1111/j.1365-2486.2005.01056.x, 2005.

Gamon, J. A., Field, C. B., Goulden, M. L., Griffin, K. L., Hartley, A. E., Joel, G., Peñuelas, J., and Valentini, R.: Relationships Between NDVI, Canopy Structure, and Photosynthesis in Three Californian Vegetation Types, Ecol. Appl., 5, 28-41, https://doi.org/10.2307/1942049, 1995.

GoK: Kenya Agricultural and Livestock Research Act, 2013 (No. 17 of 2013), available at: https://www.ecolex.org/details/legislation/kenya-agriculturaland-livestock-research-act-2013-no-17-of-2013-lexfaoc122139/ (last access: 16 September 2019), 2013.

Grace, J., San Jose, J., Meir, P., Miranda, H. S., and Montes, R. A.: Productivity and Carbon Fluxes of Tropical Savannas, J. Biogeogr., 33, 387-400, https://doi.org/10.1111/j.13652699.2005.01448.x, 2006.

Grover, S. P. P., Livesley, S. J., Hutley, L. B., Jamali, H., Fest, B., Beringer, J., Butterbach-Bahl, K., and Arndt, S. K.: Land use change and the impact on greenhouse gas exchange in north Australian savanna soils, Biogeosciences, 9, 423-437, https://doi.org/10.5194/bg-9-423-2012, 2012.

Hanson, R. S. and Hanson, T. E.: Methanotrophic Bacteria, Microbiol. Rev., 60, 439-471, 1996.

Hickman, J. E., Palm, C. A., Kiiti Mutuo, P., Melillo, J. M., and Tang, J.: Nitrous Oxide $\left(\mathrm{N}_{2} \mathrm{O}\right)$ Emissions in Response to Increasing Fertilizer Addition in Maize (Zea Mays L.) Agriculture in Western Kenya, Nutr. Cycl. Agroecosys., 100, 177-187, https://doi.org/10.1007/s10705-014-9636-7, 2014.

Hutchinson, G. L. and Mosier, A. R.: Improved Soil Cover Method for Field Measurement of Nitrous Oxide Fluxes 1, Soil Sci. Soc. Am. J., 45, 311-316, https://doi.org/10.2136/sssaj1981.03615995004500020017x, 1981.

IPCC: Climate Change 2013: The Physical Science Basis, Rationale Reference. European Environment Agency, available at: https://www.eea.europa.eu/data-and-maps/indicators/glaciers-2/ ipcc-2013-climate-change-2013 (last access: 29 November 2018), 2013.

IPCC: Refinement to the 2006 IPCC Guidelines for National Greenhouse Gas Inventories, available at: https://www. ipcc.ch/site/assets/uploads/2019/06/SB-50_TFI-side-event_ 2019-Refinement.pdf, last access: 10 March 2019.

Jacinthe, P.-A., Dick, W. A., Lal, R., Shrestha, R. K., and Bilen, S.: Effects of No-till Duration on the Methane Oxidation Capacity of Alfisols, Biol. Fert. Soils, 50, 477-486, https://doi.org/10.1007/s00374-013-0866-7, 2014.

Janssens, I. A., Lankreijer, H., Matteucci, G., Kowalski, A. S., Buchmann, N., Epron, D., and Pilegaard, K.: Productivity Overshadows Temperature in Determining Soil and Ecosystem Respiration across European Forests, Glob. Change Biol., 7, 269-278, https://doi.org/10.1046/j.1365-2486.2001.00412.x, 2001.

K'Otuto, G. O., Otieno, D. O., Seo, B., Ogindo, H. O., and Onyango, J. C.: Carbon Dioxide Exchange and Biomass Productivity of the Herbaceous Layer of a Managed Tropical Humid Savanna Ecosystem in Western Kenya, J. Plant Ecol., 6, 286-297, https://doi.org/10.1093/jpe/rts038, 2013.
Lal, R.: Soil Carbon Sequestration Impacts on Global Climate Change and Food Security, Science, 304, 1623-1627, https://doi.org/10.1126/science.1097396, 2004.

Lal, R.: Challenges and Opportunities in Soil Organic Matter Research, Eur. J. Soil Sci., 60, 158-169, https://doi.org/10.1111/j.1365-2389.2008.01114.x, 2009.

La Scala, N., Marques, J., Pereira, G. T., and Corá, J. E.: Carbon Dioxide Emission Related to Chemical Properties of a Tropical Bare Soil, Soil Biology Biochem., 32, 1469-1473, https://doi.org/10.1016/S0038-0717(00)00053-5, 2000.

Lees, K. J., Quaife, T., Artz, R. R. E., Khomik, M., and Clark, J. M.: Potential for Using Remote Sensing to Estimate Carbon Fluxes across Northern Peatlands - A Review, Sci. Total Environ., 615, 857-874, https://doi.org/10.1016/j.scitotenv.2017.09.103, 2018.

Livesley, S. J., Grover, S., Hutley, L. B., Jamali, H., ButterbachBahl, K., Fest, B., Beringer, J., and Arndt, S. K.: "Seasonal Variation and Fire Effects on $\mathrm{CH}_{4}, \mathrm{~N}_{2} \mathrm{O}$ and $\mathrm{CO}_{2}$ Exchange in Savanna Soils of Northern Australia, Agr. Forest Meteorol., 151, 1440-1452, https://doi.org/10.1016/j.agrformet.2011.02.001, 2011.

Macdonald, L. M., Paterson, E., Dawson, L. A., and McDonald, A. J. S.: Defoliation and Fertiliser Influences on the Soil Microbial Community Associated with Two Contrasting Lolium Perenne Cultivars, Soil Biol. Biochem., 38, 674-682, https://doi.org/10.1016/j.soilbio.2005.06.017, 2006.

Mapanda, F., Mupini, J., Wuta, M., Nyamangara, J., and Rees, R. M.: A Cross-Ecosystem Assessment of the Effects of Land Cover and Land Use on Soil Emission of Selected Greenhouse Gases and Related Soil Properties in Zimbabwe, Eur. J. Soil Sci., 61, 721-733, https://doi.org/10.1111/j.1365-2389.2010.01266.x, 2010.

Mapanda, F., Wuta, M., Nyamangara, J., and Rees, R. M.: Effects of Organic and Mineral Fertilizer Nitrogen on Greenhouse Gas Emissions and Plant-Captured Carbon under Maize Cropping in Zimbabwe, Plant Soil, 343, 67-81, https://doi.org/10.1007/s11104-011-0753-7, 2011.

Marteau, R., Sultan, B., Moron, V., Alhassane, A., Baron, C., and Traoré, S. B.: The Onset of the Rainy Season and Farmers' Sowing Strategy for Pearl Millet Cultivation in Southwest Niger, Agr. Forest Meteorol., 151, 1356-1369, https://doi.org/10.1016/j.agrformet.2011.05.018, 2011.

Merbold, L., Ardö, J., Arneth, A., Scholes, R. J., Nouvellon, Y., de Grandcourt, A., Archibald, S., Bonnefond, J. M., Boulain, N., Brueggemann, N., Bruemmer, C., Cappelaere, B., Ceschia, E., El-Khidir, H. A. M., El-Tahir, B. A., Falk, U., Lloyd, J., Kergoat, L., Le Dantec, V., Mougin, E., Muchinda, M., Mukelabai, M. M., Ramier, D., Roupsard, O., Timouk, F., Veenendaal, E. M., and Kutsch, W. L.: Precipitation as driver of carbon fluxes in 11 African ecosystems, Biogeosciences, 6, 1027-1041, https://doi.org/10.5194/bg-6-1027-2009, 2009.

Metcalfe, D. B., Fisher, R. A., and Wardle, D. A.: Plant communities as drivers of soil respiration: pathways, mechanisms, and significance for global change, Biogeosciences, 8, 2047-2061, https://doi.org/10.5194/bg-8-2047-2011, 2011.

Meyer, W. B. and Turner, B. L.: Human Population Growth and Global Land-Use/Cover Change, Annu. Rev. Ecol. Syst., 23, 3961, 1992.

Moyano, F. E., Manzoni, S., and Chenu, C.: Responses of soil heterotrophic respiration to moisture availability: An explo- 
ration of processes and models, Soil Biol. Biochem., 59, 72-85, https://doi.org/10.1016/j.soilbio.2013.01.002, 2013.

Nandwa, S. M.: Soil Organic Carbon (SOC) Management for Sustainable Productivity of Cropping and Agro-Forestry Systems in Eastern and Southern Africa, Nutr. Cycl. Agroecosys., 61, 143158, https://doi.org/10.1023/A:1013386710419, 2001.

O'Connell, A. M.: Microbial Decomposition (Respiration) of Litter in Eucalypt Forests of South-Western Australia: An Empirical Model Based on Laboratory Incubations, Soil Biol. Biochem., 22, 153-160, https://doi.org/10.1016/00380717(90)90080-J, 1990.

Oduor, C. O., Karanja, N., Onwong'a, R., Mureithi, S., Pelster, D., and Nyberg, G.: Pasture Enclosures Increase Soil Carbon Dioxide Flux Rate in Semiarid Rangeland, Kenya, Carbon Balance and Management, 13, 24, https://doi.org/10.1186/s13021-0180114-4, 2018.

Oertel, C., Matschullat, J., Zurba, K., Zimmermann, F., and Erasmi, S.: Greenhouse Gas Emissions from Soils - A Review, Geochemistry, 76, 327-352, https://doi.org/10.1016/j.chemer.2016.04.002, 2016.

Ondier, J., Okach, D. O., John, O. C., and Otieno, D. O.: Influence of Rainfall Amount and Livestock Grazing on Soil Respiration in a Moist Kenyan Savannah, Afr. J. Ecol., 58, 92-99, https://doi.org/10.1111/aje.12670, 2020.

Otieno, D. O., K'Otuto, G. O., Maina, J. N., Kuzyakov, Y., and Onyango, J. C.: Responses of Ecosystem Carbon Dioxide Fluxes to Soil Moisture Fluctuations in a Moist Kenyan Savanna, J. Trop. Ecol., 26, 605-618, 2010.

Parkin, T. B. and Venterea, R. T.: Sampling protocols chapter 3. Chamber-based trace gas flux measurements, in: Sampling Protocols, edited by: Follett, R. F., U.S. Dep. of Agric.-Agric. Res. Serv., available at: https://www.ars.usda.gov/SP2UserFiles/Program/212/Chapter3. GRACEnetTraceGasSamplingProtocols.pdf (last access: 13 April 2020), 2010.

Parkin, T. B., Venterea, R. T., and Hargreaves, S. K.: Calculating the Detection Limits of Chamber-Based Soil Greenhouse Gas Flux Measurements, J. Environ. Qual., 41, 705, https://doi.org/10.2134/jeq2011.0394, 2012.

Patton, B. D., Dong, X., Nyren, P. E., and Nyren, A.: Effects of Grazing Intensity, Precipitation, and Temperature on Forage Production, Rangeland Ecol. Manag., 60, 656-665, https://doi.org/10.2111/07-008R2.1, 2007.

Pellikka, P. K. E., Clark, B. J. F., Gonsamo Gosa, A., Himberg, N., Hurskainen, P., Maeda, E., Mwang'ombe, J., Omoro, L. M. A., and Siljander, M.: Agricultural Expansion and Its Consequences in the Taita Hills, Kenya, Developments in Earth Surface Processes, 16, 165-179, https://doi.org/10.1016/B978-0-444-595591.00013-X, 2013.

Pellikka, P. K. E., Heikinheimo, V., Hietanen, J., Schäfer, E., Siljander, M., and Heiskanen, J.: Impact of Land Cover Change on Aboveground Carbon Stocks in Afromontane Landscape in Kenya, Appl. Geogr., 94, 178-189, https://doi.org/10.1016/j.apgeog.2018.03.017, 2018.

Pelster, D., Rufino, M., Rosenstock, T., Mango, J., Saiz, G., Diaz-Pines, E., Baldi, G., and Butterbach-Bahl, K.: Smallholder farms in eastern African tropical highlands have low soil greenhouse gas fluxes, Biogeosciences, 14, 187-202, https://doi.org/10.5194/bg-14-187-2017, 2017.
Pfeifer, M., Platts, P. J., Burgess, N. D., Swetnam, R. D., Willcock, S., Lewis, S. L., and Marchant, R.: Land Use Change and Carbon Fluxes in East Africa Quantified Using Earth Observation Data and Field Measurements, Environ. Conserv., 40, 241-252, 2013.

Pinto, A. d. S., Bustamante, M. M. C., Kisselle, K., Burke, R., Zepp, R., Viana, L. T., Varella, R. F., and Molina, M.: Soil Emissions of $\mathrm{N}_{2} \mathrm{O}$, NO, and $\mathrm{CO}_{2}$ in Brazilian Savannas: Effects of Vegetation Type, Seasonality, and Prescribed Fires, J. Geophys. Res.-Atmos., 107, LBA 57-1-LBA 57-9, https://doi.org/10.1029/2001JD000342, 2002.

Raich, J. W. and Tufekciogul, A.: Vegetation and Soil Respiration: Correlations and Controls, Biogeochemistry, 48, 71-90, https://doi.org/10.1023/A:1006112000616, 2000.

R Core Team: R: A language and environment for statistical computing, R Foundation for Statistical Computing, Vienna, Austria, available at: https://www.R-project.org/ (last access: 13 April 2020), 2018.

Rees, R. M., Wuta, M., Furley, P. A., and Li, C.: Nitrous Oxide Fluxes from Savanna (Miombo) Woodlands in Zimbabwe, J. Biogeogr., 33, 424-437, 2006.

Reichstein, M., Rey, A., Freibauer, A., Tenhunen, J., Valentini, R., Banza, J., and Casals, P.: Modeling Temporal and Large-Scale Spatial Variability of Soil Respiration from Soil Water Availability, Temperature and Vegetation Productivity Indices, Global Biogeochem. Cy., 17, 1104, https://doi.org/10.1029/2003GB002035, 2003.

Rey, A., Pegoraro, E., Oyonarte, C., Were, A., Escribano, P., and Raimundo, J.: Impact of Land Degradation on Soil Respiration in a Steppe (Stipa Tenacissima L.) Semi-Arid Ecosystem in the SE of Spain, Soil Biol. Biochem., 43, 393-403, https://doi.org/10.1016/j.soilbio.2010.11.007, 2011.

Rochette, P.: Towards a Standard Non-Steady-State Chamber Methodology for Measuring Soil $\mathrm{N}_{2} \mathrm{O}$ Emissions, Anim. Feed Sci. Tech., 166-167, 141-146, https://doi.org/10.1016/j.anifeedsci.2011.04.063, 2011.

Rochette, P. and Bertrand, N.: Soil Air Sample Storage and Handling Using Polypropylene Syringes and Glass Vials, Can. J. Soil Sci., 83, 631-637, https://doi.org/10.4141/S03-015, 2003.

Rosenkranz, P., Brüggemann, N., Papen, H., Xu, Z., Seufert, G., and Butterbach-Bahl, K.: $\mathrm{N}_{2} \mathrm{O}$, $\mathrm{NO}$ and $\mathrm{CH}_{4}$ exchange, and microbial $\mathrm{N}$ turnover over a Mediterranean pine forest soil, Biogeosciences, 3, 121-133, https://doi.org/10.5194/bg-3-1212006, 2006.

Rosenstock, T. S., Mpanda, M., Pelster, D. E., ButterbachBahl, K., Rufino, M. C., Thiong'o, M., and Mutuo, P.: Greenhouse Gas Fluxes from Agricultural Soils of Kenya and Tanzania: GHG Fluxes from Agricultural Soils of East Africa, J. Geophys. Res.-Biogeo., 121, 1568-1580, https://doi.org/10.1002/2016JG003341, 2016.

Scholes, M. C., Martin, R., Scholes, R. J., Parsons, D., and Winstead, E.: $\mathrm{NO}$ and $\mathrm{N}_{2} \mathrm{O}$ Emissions from Savanna Soils Following the First Simulated Rains of the Season, Nutr. Cycl. Agroecosys., 48, 115-122, https://doi.org/10.1023/A:1009781420199, 1997.

Scrimgeour, C.: Soil Sampling and Methods of Analysis, in: Experimental Agriculture, 2nd Edn., edited by: Carter, M. R. and Gregorich, E. G., CRC Press, Boca Raton, Fl, USA, 437-437, https://doi.org/10.1017/S0014479708006546, 2008.

Serrano-Silva, N., Sarria-Guzmán, Y., Dendooven, L., and LunaGuido, M.: Methanogenesis and Methanotrophy in Soil: A Re- 
view, Pedosphere, 24, 291-307, https://doi.org/10.1016/S10020160(14)60016-3, 2014.

Søe, A. R. B., Giesemann, A., Anderson, T.-H., Weigel, H.-J., and Buchmann, N.: Soil Respiration under Elevated $\mathrm{CO}_{2}$ and Its Partitioning into Recently Assimilated and Older Carbon Sources, Plant Soil, 262, 85-94, https://doi.org/10.1023/B:PLSO.0000037025.78016.9b, 2004.

Tufekcioglu, A., Raich, J. W., Isenhart, T. M., and Schultz, R. C.: Soil Respiration within Riparian Buffers and Adjacent Crop Fields, Plant Soil, 229, 117-124, 2001.

Tuure, J., Korpela, A., Hautala, M., Hakojärvi, M., Mikkola, H., Räsänen, M., and Duplissy, J.: Comparison of Surface Foil Materials and Dew Collectors Location in an Arid Area: A One-Year Field Experiment in Kenya, Agr. Forest Meteorol., 276-277, 107613, https://doi.org/10.1016/j.agrformet.2019.06.012, 2019.

Valentini, R., Arneth, A., Bombelli, A., Castaldi, S., Cazzolla Gatti, R., Chevallier, F., Ciais, P., Grieco, E., Hartmann, J., Henry, M., Houghton, R. A., Jung, M., Kutsch, W. L., Malhi, Y., Mayorga, E., Merbold, L., Murray-Tortarolo, G., Papale, D., Peylin, P., Poulter, B., Raymond, P. A., Santini, M., Sitch, S., Vaglio Laurin, G., van der Werf, G. R., Williams, C. A., and Scholes, R. J.: A full greenhouse gases budget of Africa: synthesis, uncertainties, and vulnerabilities, Biogeosciences, 11, 381-407, https://doi.org/10.5194/bg-11-381-2014, 2014.

van Reeuwijk, L. P.: Procedures for Soil Analysis, 6th Edn., Technical Paper, International Soil Reference an Information Centre, Wageningen, 2002.

van Vegten, J. A.: Thornbush invasion in a savanna ecosystem in eastern Botswana, Vegetation, 56, 3-7, https://doi.org/10.1007/BF00036129, 1984.
Wachiye, S., Merbold, L., Pellikka, P. K. E., Rinne, J., Vesala, T., Leitner, S., and Räsänen, M.: Final data for "Soil Greenhouse Gas Emissions under Different Land-Use Types in Savanna Ecosystems of Kenya", figshare, available at: https://figshare.com/articles/Final_data_for_Soil_ Greenhouse_Gas_Emissions_under_Different_Land-Use_ Types_in_Savanna_Ecosystems_of_Kenya_/11673579, last access: 27 January 2020.

Waswa, F. and Mburu, J.: Potential of Dryland Farming in Kenya and Environmental Implications, in: School of Environmental Studies and Human Sciences, Kenyatta University, available at: https://ir-library.ku.ac.ke/handle/123456789/12571 (last access: 15 September 2019), 2006.

Wilcke, W. and Lilienfein, J.: Nutrient Leaching in Oxisols under Native and Managed Vegetation in Brazil, Soil Sci. Soc. Am. J., 69, 1152-1161, https://doi.org/10.2136/sssaj2004.0350, 2005.

Williams, C. A., Hanan, N. P., Neff, J. C., Scholes, R. J., Berry, J. A., Denning, A. S., and Baker, D. F.: Africa and the Global Carbon Cycle, Carbon Balance and Management, 2, 3, https://doi.org/10.1186/1750-0680-2-3, 2007.

Wilsey, B. J., Parent, G., Roulet, N. T., Moore, T. R., and Potvin, C.: Tropical Pasture Carbon Cycling: Relationships between C Source/Sink Strength, above-Ground Biomass and Grazing, Ecol. Lett., 5, 367-376, https://doi.org/10.1046/j.14610248.2002.00322.x, 2002. 